\title{
Use and uptake of web-based therapeutic interventions amongst Indigenous populations in Australia, New Zealand, the United States of America and Canada: a scoping review
}

Rachel Reilly ${ }^{1,2^{*}}$, Jacqueline Stephens ${ }^{1,3}$, Jasmine Micklem ${ }^{4}$, Catalin Tufanaru ${ }^{5}$, Stephen Harfield ${ }^{1}$, Ike Fisher ${ }^{6}$, Odette Pearson ${ }^{1}$ and James Ward ${ }^{1}$

\begin{abstract}
Background: Barriers to receiving optimal healthcare exist for Indigenous populations globally for a range of reasons. To overcome such barriers and enable greater access to basic and specialist care, developments in information and communication technologies are being applied. The focus of this scoping review is on web-based therapeutic interventions (WBTI) that aim to provide guidance, support and treatment for health problems.

Objectives: This review identifies and describes international scientific evidence on WBTI used by Indigenous peoples in Australia, New Zealand, Canada and USA for managing and treating a broad range of health conditions.

Eligibility criteria: Studies assessing WBTI designed for Indigenous peoples in Australia, Canada, USA and New Zealand, that were published in English, in peer-reviewed literature, from 2006 to 2018 (inclusive), were considered for inclusion in the review. Studies were considered if more than $50 \%$ of participants were Indigenous, or if results were reported separately for Indigenous participants.
\end{abstract}

Sources of evidence: Following a four-step search strategy in consultation with a research librarian, 12 databases were searched with a view to finding both published and unpublished studies.

Charting methods: Data was extracted, synthesised and reported under four main conceptual categories: (1) types of WBTI used, (2) community uptake of WBTI, (3) factors that impact on uptake and (4) conclusions and recommendations for practice.

\footnotetext{
* Correspondence: rachel.reilly@sahmri.com

'Aboriginal Health Equity, South Australian Health and Medical Research Institute, Adelaide, South Australia, Australia

${ }^{2}$ College of Medicine and Public Health, Flinders University, Bedford Park, South Australia, Australia

Full list of author information is available at the end of the article
}

(c) The Author(s). 2020 Open Access This article is licensed under a Creative Commons Attribution 4.0 International License, which permits use, sharing, adaptation, distribution and reproduction in any medium or format, as long as you give appropriate credit to the original author(s) and the source, provide a link to the Creative Commons licence, and indicate if changes were made. The images or other third party material in this article are included in the article's Creative Commons licence, unless indicated otherwise in a credit line to the material. If material is not included in the article's Creative Commons licence and your intended use is not permitted by statutory regulation or exceeds the permitted use, you will need to obtain permission directly from the copyright holder. To view a copy of this licence, visit http://creativecommons.org/licenses/by/4.0/ The Creative Commons Public Domain Dedication waiver (http://creativecommons.org/publicdomain/zero/1.0/) applies to the data made available in this article, unless otherwise stated in a credit line to the data. 
(Continued from previous page)

Results: A total of 31 studies met the inclusion criteria. The WBTI used were interactive websites, screening and assessment tools, management and monitoring tools, gamified avatar-based psychological therapy and decision support tools. Other sources reported the use of mobile apps, multimedia messaging or a mixture of intervention tools. Most sources reported moderate uptake and improved health outcomes for Indigenous people. Suggestions to improve uptake included as follows: tailoring content and presentation formats to be culturally relevant and appropriate, customisable and easy to use.

Conclusions: Culturally appropriate, evidence-based WBTI have the potential to improve health, overcome treatment barriers and reduce inequalities for Indigenous communities. Access to WBTI, alongside appropriate training, allows health care workers to better support their Indigenous clients. Developing WBTI in partnership with Indigenous communities ensures that these interventions are accepted and promoted by the communities.

Keywords: e-mental health, Digital technology, Aboriginal and Torres Strait Islander, Therapeutic intervention, Mobile health, e-health, Mental health, Chronic disease, Infectious disease, Information Technology, App

\section{Background}

Indigenous populations in Australia, New Zealand, the United States of America (USA) and Canada carry a greater burden of ill-health than the general populations in their respective countries [1]. In each of these countries, Indigenous populations also experience barriers to receiving optimal health care due to mistrust of the health system resulting from historic and current mistreatment, language and cultural differences and living in geographically remote locations [1]. Globally, developments in health information and communication technologies (ICT) have been applied to overcome such barriers and to enable greater access to basic and specialist care [2].

In recent years, technological advances have also led to the development of therapeutic interventions delivered electronically for a range of health conditions. The focus of this review is on web-based therapeutic interventions (WBTI), which are self-guided or clinicianassisted programmes delivered via the internet that aim to provide guidance, support and treatment for health problems. The proliferation of mobile devices, including smart phones and electronic tablets, means that webbased programmes and mobile applications ("apps") can be accessed at low cost by a range of populations, including culturally and linguistically diverse, or other populations who may be otherwise disengaged with the health system for a range of reasons.

In Australia, despite the challenges inherent in remote living, compounded by socioeconomic disadvantage, Aboriginal and Torres Strait Islander populations have high rates of social platform use, indicating high levels of internet connectivity [3]. The recent roll-out of the "National Broadband Network" (NBN) in non-urban areas and other advances in technology have resulted in the rise of telecommunication access in remote areas, where internet access was previously limited [4]. In recent years, the increase in use of social platforms has been significantly greater amongst Aboriginal and Torres Strait Islanders compared with that for all Australians, and a high level of engagement with social platforms has been evident in the health sector [5-7]. Together, advancements and high level use of ICT by Indigenous Australians across all areas of remoteness and sociodemographic spectrum clearly indicate a potential to engage with individuals directly through social platforms, particularly with younger people.

The use of digital health platforms has been advocated to incorporate a wider approach to include social determinants of health and wellbeing [5], given the feasibility of capturing personalised health-related social and behavioural information that was not previously accessible, with direct implications to people living with chronic diseases. Worldwide, there are over 250,000 different consumer-targeted mobile health apps, though few have been rigorously evaluated regarding the accuracy of information they provide, privacy and digital security protections, and their usability, functionality and effectiveness in the context of health [8]. As the use of online therapies continues to grow, this review of international evidence on WBTI for health conditions amongst Indigenous populations is timely.

A previous scoping study has examined the evidence for the effectiveness of web-based and mobile technologies in health promotion, specifically to reach Indigenous Australians [9]. This valuable piece of work focused on social media and mobile apps primarily for smoking cessation, many of which did not appear in the peerreviewed literature. The current review provides an update on the peer-reviewed evidence of the acceptability, validity and effectiveness of WBTI for a broad range of health conditions, extending the review to include WBTI developed with Indigenous people internationally for communicable and non-communicable diseases, mental health conditions (including the broader concept of social and emotional wellbeing), or issues relating to the 
use of harmful substances, and problem gambling. The objective of this scoping review is to identify and describe the available international scientific evidence on WBTI used by Indigenous peoples in Australia, New Zealand, Canada and USA for managing and treating health conditions. These four countries were included due to similar persistent patterns of inequities that have arisen in these countries since colonisation, as well as geographic and demographic similarities such as remoteness from health services and differing language, culture and concepts of health and illness from the dominant culture [1]. Additionally, these four countries have other commonalities which allow for comparison; they are developed, democratic, wealthy countries with similar standard of living and life expectancy [10].

\section{Methods}

The study protocol for this scoping review has been published previously [11]. Methods followed the procedures outlined by the Joanna Briggs Institute [12, 13] with reporting adhering to the Preferred Reporting Items for Systematic Reviews and Meta-analyses (PRISMA) guidelines scoping review extension [14]. The relevant PRISMA checklist is included as an additional file.

\section{Information sources}

A systematic search was conducted of the following databases: PubMed, CINAHL, Embase, ATSIHealth via Informit online, Web of Science, APAIS Health databases, Australian Indigenous Health InfoNet and the Primary Health Care Research Information Service (PHCRIS). A search for unpublished studies was conducted by accessing Mednar, Trove, Google, OCLC WorldCatDissertations and Theses, and Proquest Dissertations and Theses. The search in Trove was limited to theses only, as the assumption was made that other publication types would be captured in the other databases. To capture additional literature, a search of websites and clearing houses that provided information, links and resources relating to Indigenous health in each of the four countries that are the focus of this review was conducted using initial keywords including the following: Indigenous, Aboriginal, Torres Strait Islander, Maori, First Nations, First Peoples, Metis, Inuit, Native American, eHealth, telehealth, internet-based intervention and web-based therapeutic tool.

\section{Search strategy}

As outlined in the scoping review protocol [11], a fourstep search strategy was followed in consultation with a research librarian, with a view to finding both published and unpublished studies. An initial limited search of PubMed was undertaken. The final search strategy for PubMed can be found in Table 1. An analysis of the text words contained in the titles and abstracts, and of the index terms used to describe articles then informed the development of search strategies tailored for each information source. A second search using all identified keywords and index terms was undertaken across all other information sources. The reference list of all studies selected for inclusion was screened for additional studies. The search strategy allowed for authors to be contacted and experts consulted with a view to accessing any unpublished data or for clarification of published information; however, this was not necessary in practice. The search was conducted on 10 April, 2019.

\section{Inclusion criteria \\ Date range}

Studies published from 2006 to 2018 (inclusive) in English were considered for inclusion. This timeframe was

Table 1 Search Strategy for PubMed

\begin{tabular}{|c|c|}
\hline Category & Search terms \\
\hline $\begin{array}{l}\text { Population of } \\
\text { interest }\end{array}$ & $\begin{array}{l}\text { (("Oceanic Ancestry Group"[mh] OR Aborig*[tw] OR Indigen*[tw] OR (Torres Strait[tw] AND Islander*[tw]) OR "health services, } \\
\text { indigenous"[mh]) AND (.au[ad] OR australia[ad] OR Australia[mh] OR Australia[tiab] OR Northern Territory[tiab] OR Northern } \\
\text { Territory[ad] OR Tasmania[tiab] OR Tasmania[ad] OR New South Wales[tiab] OR New South Wales[ad] OR Victoria[tiab] OR } \\
\text { Victoria[ad] OR Queensland[tiab] OR Queensland[ad])) OR Native American[tiab] OR Maori*[tiab] OR (indigenous[tiab] AND new } \\
\text { zealand[tiab]) OR "Indians, North American"[mh] OR "Inuits"[mh] OR Inuit*[tiab] OR first nation*[tiab] OR "Alaska Natives"[mh] OR } \\
\text { metis[tiab] OR Eskimo*[tiab] OR Canada[mh] OR United States[mh] }\end{array}$ \\
\hline Intervention & $\begin{array}{l}\text { "telemedicine"[mh] OR telemed*[tiab] OR ehealth[tiab] OR e-health[tiab] OR web*[tiab] OR internet[tiab] OR computer*[tiab] OR } \\
\text { mobile[tiab] OR app*[tiab] OR apps[tiab] OR blog*[tiab] OR "social media"[tiab] OR iphone*[tiab] OR smartphone*[tiab] OR "smart } \\
\text { phone*"[tiab] }\end{array}$ \\
\hline Health issues & $\begin{array}{l}\text { ("mental disorders"[mh] OR "gambling"[mh] OR "chronic disease"[mh] OR "exercise"[mh] OR "delivery of health care"[mh] OR "self } \\
\text { care"[mh] OR "disease management"[mh] OR "nutrition therapy"[mh] OR "health behavior"[mh] OR "psychotherapy"[mh] OR } \\
\text { "patient acceptance of health care"[mh] OR depress*[tiab] OR anxiety[tiab] OR suicid*[tiab] OR "stress management[tiab] OR } \\
\text { addict*[tiab] OR drug*[tiab] OR methamphetamine*[tiab] OR alcohol*[tiab] OR ice[tiab] OR meth[tiab] OR amphetamine*[tiab] OR } \\
\text { heroin[tiab] OR inhalant*[tiab] OR marijuana[tiab] OR cannabis[tiab] OR morphine[tiab] OR buprenorphine[tiab] OR } \\
\text { methadone[tiab] OR speed[tiab] OR crystal[tiab] OR LSD[tiab] OR ecstasy[tiab] OR cocaine[tiab] OR GHB[tiab] OR MDMA[tiab] OR } \\
\text { ketamine[tiab] OR solvent*[tiab] OR opioid*[tiab] OR opiate*[tiab] OR narcotic*[tiab] OR illicit[tiab] OR binge drink*[tiab] OR } \\
\text { tobacco[tiab] OR smok*[tiab] OR wellbeing[tiab] OR well being[tiab] OR nutrition[tiab] OR diet[tiab] OR medication[tiab] OR } \\
\text { adherence[tiab] OR complian*[tiab] OR self manag*[tiab] OR pain manag*[tiab]) }\end{array}$ \\
\hline
\end{tabular}


considered sufficient to capture up-to-date evidence on WBTI that have grown in popularity in recent years.

\section{Publication status}

Peer-reviewed and grey literature meeting the inclusion criteria were considered for inclusion.

\section{Participants}

Studies assessing WBTI designed for Indigenous peoples of any age in Australia, Canada, USA and New Zealand were considered for inclusion in the review. Participants could be accessing the WBTI to prevent, manage or treat their own health condition; or could be healthcare providers, friends or family members accessing a WBTI to assist an Indigenous person with a health condition. Studies were considered if more than $50 \%$ of participants were Indigenous, or if results were reported separately for the Indigenous participants.

\section{Concept}

The focus of this review was on the use and uptake of WBTI by Indigenous people. The range of possible health issues the WBTI could address was deliberately broad and included chronic physical illness, communicable disease, mental health conditions and issues relating to social and emotional wellbeing, use of harmful substances or gambling. Studies were considered for inclusion if they provided information on WBTI used by individuals or groups: either autonomously or with assistance, to assess, manage or treat health conditions by (a) modifying lifestyle behaviours, (b) promoting social and emotional wellbeing and resilience, (c) supporting adherence to treatment regimens, (d) increasing motivation to reduce risky behaviours and (e) providing and supporting strategies to reduce dependence on alcohol, prescription drugs, illicit substances or gambling. Evaluations of websites that only provide health education without any interactive or therapeutic content were excluded. This included interventions involving health information kiosks or telehealth as the sole intervention strategy.

\section{Context}

Health-related WBTI accessed in any setting in Australia, New Zealand, Canada and USA were included.

\section{Selection of sources}

Following the search, all identified citations were uploaded into Endnote ${ }^{\mathrm{TM}}$ (Version X8.1, Clarivate Analytics, Philadelphia, USA) and duplicates removed. Citations were then entered into an online systematic review management system (www.covidence.org, 2019, Veritas Health Innovation Ltd, Melbourne, Australia). Titles and abstracts were screened against the inclusion criteria by one researcher (RR), as well as independently by one of two other researchers (SH, IF). Disagreements were resolved through discussion between all three reviewers. Studies that potentially met the inclusion criteria were retrieved in full and imported into Covidence for full text review. The full texts of selected studies were assessed in detail against the inclusion criteria by at least two reviewers (RR, and either SH, FS or IF). Full text studies that did not meet the inclusion criteria were excluded and reasons for exclusion recorded.

\section{Data charting and synthesis}

Two data extraction tools were developed for this scoping review [11], which were further refined during the data charting process. This tool facilitated the extraction of the data mapped to the variables outlined in Table 2. Extracted data was synthesised and reported under four main conceptual categories: (1) types of WBTI used, (2) community uptake of WBTI, (3) factors that impact on uptake and (4) conclusions and recommendations for practice.

\section{Results}

\section{Sources of evidence}

The systematic searches identified 8182 references and one additional reference was identified through other sources (Fig. 1). After duplicates were removed, there were 1618 unique papers for review. The large number of duplicates stems from many studies being duplicated across multiple databases. Title and abstract screening excluded 1420 references, and a further 166 papers were excluded on full-text review, resulting in 31 studies meeting the inclusion criteria for this scoping review.

\section{Characteristics of sources}

As shown in Table 3, 11 (34\%) sources were from the USA [15-25] and nine (28\%) sources were from New Zealand [26-34], with the remainder from Australia (12, $38 \%$ ) [35-45]. As there were no studies from Canada, the findings reported from here on pertain to New Zealand, the USA and Australia. The majority reported evaluation studies (52\%) [16-18, 22, 23, 25, 29, 31, 32, $34-36,38,39,43,45]$ and had prospective (94\%) data collection [15-28, 30-33, 35-43, 45]. There was an increasing number of publications over time. As shown in Table 4, health topics addressed in the reported studies were varied; however, mental health $(32 \%)[24,27,31,32,36,37$, $39,41-43]$ and substance use (19\%) [16, 18, 21, 22, 28] were the two prominent issues targeted. Most sources reported studies that focused on interventions with consumers $(82 \%)$, although four (18\%) [24, 34, 36, 37, 39, 43] sources reported the use of WBTI to support healthcare workers. There were 
Table 2 Data extraction variables

\begin{tabular}{|c|c|}
\hline Variable name & Description \\
\hline Author & The surname of the first author of the source publication. \\
\hline Year & Year study published. \\
\hline Country & Country and population where the study was conducted. \\
\hline WBTI & Name of the web-based therapeutic intervention. \\
\hline Aim & Purpose of the WBTI (e.g. treatment, education, adherence, chronic disease management) \\
\hline $\begin{array}{l}\text { Health } \\
\text { condition }\end{array}$ & The health condition targeted by the WBTI. \\
\hline Participants & Descriptive demographics about the study population \\
\hline Delivery mode & WBTI components, frequency intensity and duration of use, self or clinician administered, or clinician assisted \\
\hline Context & $\begin{array}{l}\text { The setting where the study was conducted (e.g. health service or community setting, geographic location (urban, rural, remote), } \\
\text { other relevant details reported by authors. }\end{array}$ \\
\hline Design & The study design. \\
\hline Outcomes & The key outcome measures for the study. \\
\hline Results & Whether the WBTI had a positive or negative change, or no change. \\
\hline Explanation & Explanations provided by the authors for uptake and treatment effects. \\
\hline Findings & Author's conclusions, interpretations and recommendations. \\
\hline
\end{tabular}

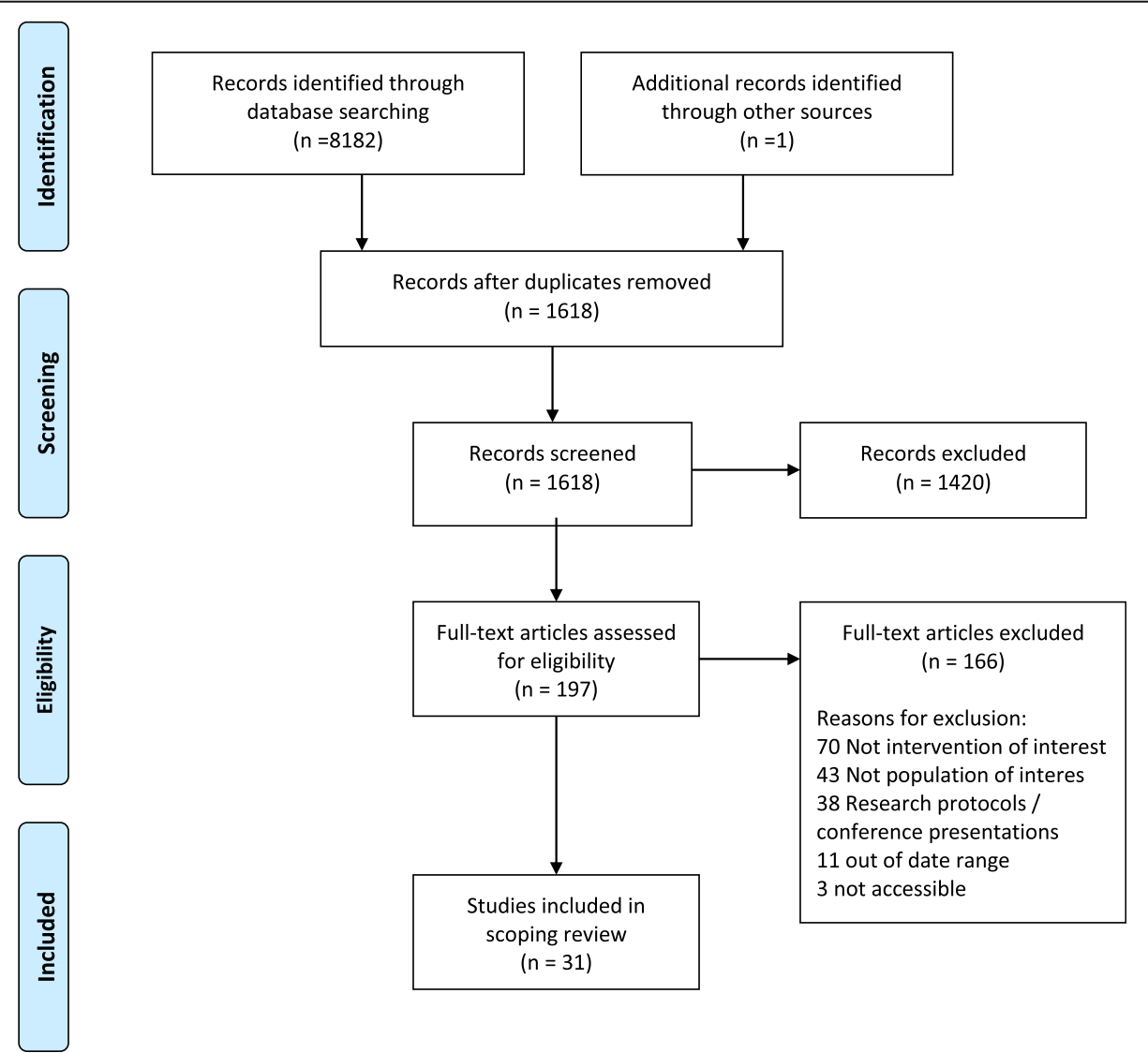

Fig. 1 PRISMA flow diagram of the complete search process 
Table 3 General characteristics of included publications

\begin{tabular}{|c|c|c|}
\hline Characteristic & Number & Percentage (\%) \\
\hline \multicolumn{3}{|l|}{ Country } \\
\hline New Zealand & 9 & $29 \%$ \\
\hline Australia & 11 & $36 \%$ \\
\hline USA & 11 & $36 \%$ \\
\hline \multicolumn{3}{|l|}{ Publication year } \\
\hline 2006-2009 & 4 & $13 \%$ \\
\hline 2010-2014 & 10 & $32 \%$ \\
\hline 2015-2018 & 17 & $55 \%$ \\
\hline \multicolumn{3}{|l|}{ Study type } \\
\hline Case study & 1 & $3 \%$ \\
\hline Evaluation study & 16 & $52 \%$ \\
\hline Feasibility trial & 4 & $13 \%$ \\
\hline Observational study & 3 & $10 \%$ \\
\hline Qualitative study & 2 & $6 \%$ \\
\hline Randomised trial & 5 & $16 \%$ \\
\hline \multicolumn{3}{|l|}{ Study design } \\
\hline Prospective & 29 & $94 \%$ \\
\hline Retrospective & 2 & $6 \%$ \\
\hline \multicolumn{3}{|l|}{ Topic } \\
\hline Cardiac care & 3 & $10 \%$ \\
\hline Diabetes & 3 & $10 \%$ \\
\hline General/nutrition & 4 & $13 \%$ \\
\hline Mental health & 11 & $36 \%$ \\
\hline Other (asthma, neonatal, otitis media) & 3 & $10 \%$ \\
\hline Smoking cessation & 2 & $6 \%$ \\
\hline Substance misuse & 5 & $16 \%$ \\
\hline \multicolumn{3}{|l|}{ Population } \\
\hline Consumers & 27 & $87 \%$ \\
\hline Healthcare workers & 4 & $13 \%$ \\
\hline Adolescents & 8 & $25 \%$ \\
\hline
\end{tabular}

no clear patterns of similarity or differences between countries in any of the variables reported.

\section{Types of WBTI used}

The types of WBTI described in the source publications are presented in Tables 4 and 5 . The majority of the interventions used in these studies were interactive websites $(n=21$, of 25 interventions in the 32 studies, 84\%), providing education modules and tutorials [15, 16, 19, 22, 25-27, 29, 36], screening and assessment tools [18, 21], management and monitoring tools [20, 23, 28, 34, 38], gamified avatar-based cognitive behaviour therapy (CBT) [31, 32] and decision support tools $[24,30]$. Seven sources reported the use of mobile "apps" [17, 33, 39, 41-43, 45], two sources incorporated the use of text or multimedia messaging service $[35,40]$ and two sources studied an intervention that used a mixture of intervention tools [37, 44].

Most interventions were self-directed ( $n=19,61.3 \%$ ), requiring the user to access the WBTI program, often according to a pre-defined schedule, without support from an outside agency or healthcare worker $[16,18,19,21-26,29-$ $34,37,38,41,42,45]$. The remainder of the interventions were either supported by a healthcare worker or other personnel [17, 20, 27, 28, 35, 36, 39, 43, 44], were supported initially but then relied on users to be self-directed thereafter [15] or were passive [40], such as the receipt of intermittent text messages that contained health messages or graphics intended to prompt a behavioural response.

\section{Uptake and effects of WBTI}

The bulk of the sources reported improved health outcomes for Indigenous people [15, 16, 18-20, 22, 24, 28, 31, 33-38, 41]. For the three studies that reported uptake, voluntary uptake of WBTI was between 30 and 56\% [15, 27, 36, 37]. The remainder of the sources had the WBTI as a prescribed component of the reported intervention or evaluation study so rate of uptake is not relevant; however, contextual factors identified by study authors as influences on uptake, use and acceptability are discussed below.

None of the WBTI approaches had a negative impact on participants. However, some WBTI were more successful than others. Two randomised clinical trials reported statistically significant differences in quantitative measures of depression amongst Indigenous adolescents (USA and NZ) who used WBTI "apps" compared to those who did not [27, 42], while a qualitative study found substantial improvements in mood amongst Maori adolescents who used a gamified app [32]. An interventional study using WBTI with Native Americans for diabetes control showed a statistically significant improvement in glycated haemoglobin levels [23], and an educational tool for preventing sudden infant death in New Zealand significantly increased the confidence of Maori people to discuss infant sleep safety with others compared with non-Indigenous people [26].

Two sources reported no impact of the intervention. In the USA, risky drinking behaviour by women living in California decreased regardless of whether they received the WBTI or "usual care" [21]. In Australia, while health messages sent via text message did not impact on clinic attendance for children with otitis media [40], the content delivered in local Indigenous languages was found to be culturally appropriate and recipients were happy to receive the information.

\section{Explanations for uptake}

While some sources provided no explicit explanations for uptake success or failure [18, 30, 35], most did. Sources suggested a variety of factors that could improve WBTI uptake; however, the most important was ensuring that 
Table 4 Multi-way cross-classification matrix: health focus, delivery mode and intervention by country

\begin{tabular}{|c|c|c|c|c|c|}
\hline \multirow[t]{2}{*}{ Health focus } & \multirow[t]{2}{*}{ Delivery mode } & \multirow[t]{2}{*}{ Intervention } & \multicolumn{3}{|c|}{ No. of studies } \\
\hline & & & Aust & NZ & USA \\
\hline \multirow[t]{6}{*}{ Mental health } & \multirow[t]{2}{*}{ Service provider } & R U Appy (Bennet-Levy) & 1 & & \\
\hline & & DM-DS(Starks) & & & 1 \\
\hline & \multirow[t]{2}{*}{ Self-administered } & Sparx (Fleming; Shepherd(2)) & & 3 & \\
\hline & & iBobbly (Povey*; Tighe) & 1.5 & & \\
\hline & \multirow[t]{2}{*}{ Administered with HCP support } & Stay Strong (Dingwall (2); Povey*; Bird) & 3.5 & & \\
\hline & & Stayin on Track (Fletcher) & 1 & & \\
\hline \multirow[t]{4}{*}{ Harmful alcohol and illicit drug use } & \multirow[t]{4}{*}{ Self-administered } & Therapeutic education system (Campbell) & & & 1 \\
\hline & & SBIRT (Gorman; Montag) & & & 2 \\
\hline & & e-SBINZ (Kypri) & & 1 & \\
\hline & & Hawk 2 (Raghupath) & & & 1 \\
\hline Smoking cessation & Self-administered & SmokingZine (Bowan; Taualii) & & & 2 \\
\hline \multirow[t]{2}{*}{ Cardiac } & Service Provider & PREDICT-CVD (Riddell; Whittaker) & & 2 & \\
\hline & Administered with HCP support & CSIRO Cardiac rehab (Bradford) & 1 & & \\
\hline \multirow[t]{3}{*}{ Diabetes } & Self-administered & Kaya Tracker (Robertson) & & & 1 \\
\hline & \multirow[t]{2}{*}{ Administered with HCP support } & Stanford IDSMW (Johnson) & & & 1 \\
\hline & & My Care Team (Levine) & & & 1 \\
\hline \multirow[t]{4}{*}{ General health/ nutrition } & \multirow[t]{3}{*}{ Self-administered } & Gigiigoo'inaan (Dellinger) & 1 & & \\
\hline & & SSB (Tonkin) & & & 1 \\
\hline & & Wellness mHealth Program (Verbiest) & 1 & & \\
\hline & Administered with HCP support & Diet Bytes (Ashman) & & 1 & \\
\hline \multirow{3}{*}{$\begin{array}{l}\text { Other: } \\
\text { • Asthma } \\
\text { • Sudden Infant Death } \\
\text { • Otitis Media }\end{array}$} & Service provider & GASP (Ram) & & 1 & \\
\hline & Self-administered & Baby Essentials online (Cowan) & & 1 & \\
\hline & Non-interactive & Otitis Media MMS (Phillips) & \multicolumn{3}{|l|}{1} \\
\hline Total health foci: 9 & $\begin{array}{l}\text { Total programmes for service providers: } 4 \\
\text { Self-administered: } 12 \\
\text { Non-interactive: } 1 \\
\text { Administered with assistance: } 6\end{array}$ & Total individual programmes: 23 & \multicolumn{3}{|c|}{$\begin{array}{l}\text { *Povey includes two } \\
\text { programmes. }\end{array}$} \\
\hline
\end{tabular}

WBTI were designed for the audience [23, 44], culturally relevant and appropriate [40, 41, 43], by having culturally relevant graphics, voices and animations [40], and showing traditional practices, culture and Indigenous peoples $[16,44]$. It was also important that content was matched to participants' values and experiences. For example, Campbell et al. [16] reported that ratings of some modules varied according to experiences of discrimination or mainstream comfort. Cultural appropriateness of the WBTI was explicitly discussed and/or evaluated in all but four sources [26, 30, 34, 35]. Where authors discussed cultural appropriateness, it was linked to better outcomes in terms of acceptability, uptake and impact, whether or not this was formally evaluated. Seven sources reported recommendations from their study populations on features to improve so as to ensure the WBTI contain a greater volume of culturally appropriate content [16, 30, 33, 34, 40, 44].

In addition, sources reported that users wanted WBTI to have an innovative and visually appealing format [43] and be useful [24, 43], interesting [24] and thoughtprovoking [24]. These interventions fostered conversations [24] and resulted in improved patient-practitioner relationship which led to better health monitoring by patients [20,29]. However, one source reported that videos sent via multimedia messaging services may be unclear or confusing and suggested that simple text messages may be more effective [40]. Users like the flexible delivery that WBTI allow $[23,38]$ and want WBTI to be easy to use [41, 43] and customisable [38]. However, users also preferred to be able to download the "app" or software for free [41]. Limited access to internet or a phone were found to be prohibitive factors by users [15, 41], with mental health workers reporting significant organisational and personal barriers to accessing mental health web-based apps [36]. Systemic or policy contexts that influenced uptake and use included the following: organisational support for the WBTI [36], access to the internet or other technology due to cost or the 
Table 5 Summary of research findings from included publications

\begin{tabular}{|c|c|c|c|c|c|c|}
\hline $\begin{array}{l}\text { First author (year) } \\
\text { Country } \\
\text { Funding }\end{array}$ & $\begin{array}{l}\text { Study population and } \\
\text { context }\end{array}$ & $\begin{array}{l}\text { Aim/method and } \\
\text { health condition }\end{array}$ & $\begin{array}{l}\text { Intervention and } \\
\text { delivery type }\end{array}$ & $\begin{array}{l}\text { Measured impacts/ } \\
\text { outcomes (results) }\end{array}$ & $\begin{array}{l}\text { Explanations provided } \\
\text { for uptake and effects }\end{array}$ & $\begin{array}{l}\text { Authors' conclusions/ } \\
\text { recommendations }\end{array}$ \\
\hline
\end{tabular}

Funding

\begin{tabular}{ll}
\hline Ashman (2016) & 27 women, 8 \\
[35] & Indigenous (aged $>17$, \\
Australia & gestation $<25$ weeks), \\
Funding: NHMRC & median age 28. 8 \\
University of & regional outpatient \\
Newcastle & settings (hospital, GP \\
& clinics, community \\
& organisations), New \\
& South Wales (NSW)
\end{tabular}

\section{Aim: To use \\ smartphones to take detailed assessments of dietary intake, and provide personalised online feedback, with dietician consultation Method: Quantitative evaluation study. The women collected image-based dietary records, completed $24-$ food frequency ques- tionnaire, as well as 3 online surveys.

3

Bennett-Levy

(2017) [36]

Australia

Funding:

Australian Federal

Government

26 health professionals Aim: To identify the (21 Indigenous) in regional centres in northern NSW.

barriers and enablers of e-mental health (e$\mathrm{MH}$ ) uptake amongst mainly Aboriginal and Torres Strait Islander health professionals. Method: Qualitative evaluation study. Trainers provided written reports and were interviewed. These data sources were analysed thematically.
Bird (2017) [37]

Australia

Funding:

Australian Federal

Government
16 Aboriginal service providers in the health and communityservice sectors in regional/rural areas of northern NSW.
Aim: 4-8-month

follow-up on use of e$\mathrm{MH}$ resources following an e-MH training programme and to determine what types of e-MH resources they used.

Method: Qualitative evaluation study. 16 semi-structured interviews were transcribed and thematically analysed.

Bowen (2012) [15] 113 American Indian Aim: To evaluate a

United States of (Al) youth (12-18 years) smoking prevention America (USA) Funding: National Cancer Institute recruited during a 6week residential summer camp for American Indian students $\left(^{\text {th }}\right.$ to $12^{\text {th }}$ grade) in Rapid City, South Dakota.

$\begin{array}{ll}\text { Bradford (2015) } & \text { Non-indigenous } \\ \text { [38] } & \text { researchers from the } \\ \text { Australia } & \text { CSIRO consulted: staff } \\ \text { Funding: } & \text { of 1 remote Aboriginal } \\ \text { Commonwealth } & \text { health service; 1 urban } \\ \text { Scientific and } & \text { Indigenous health } \\ \text { Industrial Research } & \text { institute; and cardiac/ } \\ \text { Organisation } & \text { Indigenous health } \\ \text { (CSIRO) } & \text { specialists. }\end{array}$
and cessation intervention

Method: Randomised control feasibility tria with 1-month followup. After baseline assessment, students were randomised to have regular access to the site or not. All participants completed a follow-up assessment 1-month post randomisation.

Aim: To adapt an established mobile phone delivered cardiac rehabilitation programme for Indigenous people.

Method: Consultation with stakeholders and employment of Indigenous production

$\begin{array}{ll}\text { 12-week study of "Diet } & N=17,77 \% \text { reported } \\ \text { Bytes" and "SNaQ" } & \text { dietary changes as a }\end{array}$
methods. Smartphones result of feedback. used to record dietary Core food group intake and participants consumption was received a video with reported separately for personalised advice Indigenous women. comparing their intake Intake was close to to the Australian Guidelines, then phone contact with a nutritionist.

A 3- or 2-day e-MH training programme entitled: "R U Appy" was followed by up to 5 consultation sessions (mean 2.4 sessions) Training focused on download and use of apps, with a focus on the app "Stay Strong" on one of the days.

educational

programme

("SmokingZine").

Participants were

encouraged to access it as often as they like over six weeks and had daily 1-h computer time. Modules covered education, behaviour change goals, positive values and identifying barriers to change.

Smartphone app to delivered over 6 weeks to provide cardiac rehab in the patient's home in line with their lifestyle. Includes

clinical portal,

mentoring and educational material.
Based on the personalised feedback some ate more foods from core food groups, others consumed less sugary
cons, others drinks or "junk" foods. Others changed recommendations for cooking methods fruit and dairy but Less than half the below for grains, cereals, vegetables and meat. All Indigenous women met recommendations for unsaturated spreads and oils.

Uptake of e-MH in the consultation group was moderate (22$30 \%$ of participants).

Barriers to uptake were grouped into two categories: "Organisa-

tional" and "Participant perceptions". Enablers were also grouped into two categories: "Organisational" and "Positive experience of the consultations sessions.

9 of the 16 service providers were using e-MH in their practice for a variety of purposes, including supporting social inclusion, self-care, education, referral, assessment, crisis response, and case management. Use tended not to include treatment of depression/anxiety.

$52 \%$ uptake in intervention arm. The intervention did not directly affect smoking behaviour but did alter intentions to use tobacco amongst never-smokers. participants felt they had enough information about healthy eating at the time of enrolment.

Features of the organisation acted as both barriers and facilitators to uptake. Where senior staff were supportive, uptake was greater. A good match between resources and work role led to excitement amongst participants about the possibility of using YouTube clips and apps for health education.

Participants preferred e-MH resources that were easily accessed via mobile devices. Re sources for treating anxiety/depression were not preferred, perhaps due to the professional backgrounds of participants, or because mental health concepts were not culturally relevant.

Small sample, lack of statistical power. Selection bias- high grade point average and low rate of smoking at baseline. Limited access to the Web at the camp may have reduced engagement. A "g programmes where youth can use the site together.

Modifications included Smartphone flexibility in the programme not yet duration of delivery, inclusion of positive measures, use of mentors, a meeting place for using the app and taking physical measures, changes to

The Diet Bytes method for nutrition assessment combined with the $\mathrm{SNaQ}$ tool for analysing nutritional content, with the provision of personally tailored feedback, may be a useful method for dietitians to assist 
Table 5 Summary of research findings from included publications (Continued)

\begin{tabular}{|c|c|c|c|c|c|c|}
\hline $\begin{array}{l}\text { First author (year) } \\
\text { Country } \\
\text { Funding }\end{array}$ & $\begin{array}{l}\text { Study population and } \\
\text { context }\end{array}$ & $\begin{array}{l}\text { Aim/method and } \\
\text { health condition }\end{array}$ & $\begin{array}{l}\text { Intervention and } \\
\text { delivery type }\end{array}$ & $\begin{array}{l}\text { Measured impacts/ } \\
\text { outcomes (results) }\end{array}$ & $\begin{array}{l}\text { Explanations provided } \\
\text { for uptake and effects }\end{array}$ & $\begin{array}{l}\text { Authors' conclusions/ } \\
\text { recommendations }\end{array}$ \\
\hline & & $\begin{array}{l}\text { company. Paper } \\
\text { outlines the changes } \\
\text { made following } \\
\text { consultation. }\end{array}$ & & $\begin{array}{l}\text { educational content } \\
\text { words, look and feel. }\end{array}$ & $\begin{array}{l}\text { community } \\
\text { consultation and trial. }\end{array}$ & $\begin{array}{l}\text { significantly improve } \\
\text { life expectancy }\end{array}$ \\
\hline $\begin{array}{l}\text { Campbell (2015) } \\
\text { [16] } \\
\text { USA } \\
\text { Funding: } \\
\text { National Drug } \\
\text { Abuse Treatment } \\
\text { Clinical Trials } \\
\text { Network; National } \\
\text { Institute on Drug } \\
\text { Abuse (NIDA) }\end{array}$ & $\begin{array}{l}N=40 \text { Al/ Alaska } \\
\text { Native (AN), mean age } \\
37.5 ; 47.5 \% \text { women, } \\
\text { recruited via two } \\
\text { urban outpatient drug } \\
\text { treatment } \\
\text { programmes, Northern } \\
\text { Plains and Pacific } \\
\text { North-west regions. }\end{array}$ & $\begin{array}{l}\text { Aim: To test } \\
\text { acceptability of a web- } \\
\text { based version of a } \\
\text { therapeutic education } \\
\text { system (TES) for drug } \\
\text { treatment. } \\
\text { Method: Participants } \\
\text { completed baseline } \\
\text { assessments then } 1 \\
\text { week after the } \\
\text { intervention phase, } \\
\text { follow-up assessments } \\
\text { plus qualitative } \\
\text { interview. }\end{array}$ & $\begin{array}{l}\text { Self-directed and } \\
\text { comprised } 32 \\
\text { interactive, multimedia } \\
\text { modules based on the } \\
\text { Community } \\
\text { Reinforcement } \\
\text { Approach (CRA). } \\
\text { Delivered over } 8 \\
\text { weeks on computers } \\
\text { in the treatment } \\
\text { settings. }\end{array}$ & $\begin{array}{l}\text { TES was acceptable } \\
\text { across seven } \\
\text { quantitative indices. } \\
\text { Qualitative findings } \\
\text { indicated (1) content } \\
\text { was relevant and (2) } \\
\text { acceptability would be } \\
\text { enhanced by better } \\
\text { Al/AN representation } \\
\text { across several content } \\
\text { domains, and removal } \\
\text { of content that is } \\
\text { counter to Al/AN } \\
\text { culture. }\end{array}$ & $\begin{array}{l}\text { Acceptability of } \\
\text { modules varied } \\
\text { according to personal } \\
\text { characteristics or } \\
\text { experiences of } \\
\text { participants, including } \\
\text { perceived } \\
\text { discrimination and } \\
\text { "ethnic experience". } \\
\text { Participants rated } \\
\text { those modules with } \\
\text { ST//HIV information } \\
\text { most highly. }\end{array}$ & $\begin{array}{l}\text { Evidence-based, } \\
\text { culturally informed, } \\
\text { web interventions may } \\
\text { address barriers to } \\
\text { treatment in Al/AN } \\
\text { communities. } \\
\text { Adaptations can be } \\
\text { made without losing } \\
\text { fidelity. Research } \\
\text { should incorporate } \\
\text { cultural acceptability } \\
\text { and a wider range of } \\
\text { implementation issues. }\end{array}$ \\
\hline
\end{tabular}
Funding: NZ Ministry of Health

"sessions" of use of internet link and ing in. $N$ tool for preventing 207 Maori people completed the program.

Dellinger (2018)
[17]
USA
Funding: National
Institute for
Environmental
Health Sciences;
Sault Ste. Marie
Tribe of Chippewa
Indians

$V=24$ (13 women) American), aged 25 $55+$, Great Lakes region.

ndians Method: online to basic usage data collected online. development and aims to improve nutrition via contaminants.

Method: Mixed
Baby Essentials Online was a self-directed education, 1 15-min session of 24 slides, followed by assessment of "increased confidence" (IC) promoted widely, and

Aim: To describe the acceptability of an app personalised, culturally tailored advice on fish methods-qualitative and quantitative (survey) feedback obtained during focus groups.

Dingwall (2015a)

[39]

Australia

Funding:

Government

Dingwall (2015b)

[43]

Australia

Funding:

Government
$N=138$ (70\% women, Aim: To evaluate 35\% Indigenous), aged 19-74 ( $M=40.41$, SD 12.86) service proawareness, knowledge and confidence in emental health and the viders working with In- AlMhi Stay Strong App digenous people in the Northern Territory
Gigiigoo'inaan [Our Fish] is an app delivered on mobile that provides personalised risk and benefit information on fish species based on user input information.

15 service providers from rural and remote health services working with Indigenous people in the Northern Territory,
Australian Federa

Australian Federal Anishinaabe (Native "Gigiigoo'inaan", which phone and/or internet

f Maori participants, 53 rated their $\mathrm{IC}$ as "low" and 154 rated their IC as "high."

The greater IC in Maori with no greater time per slide may reflect lower starting knowledge and confidence

$61 \%$ said they would consume more fish if they had regular

access to the app; $75 \%$ agreed the app was useful, culturally appropriate and helped them identify fish to eat.

However, some reported confusion about encouragement to eat fish combined with warnings re contaminant levels. for service providers.
Face-to-face training programme "Yarning about Indigenous mental health using the AIMhi Stay Strong App". Duration not provided. fidence and use of $e-$ mental health tools with Indigenous clients.

Aim: To assess

Clinician-assisted

acceptability, feasibility, Interactive app (AIMh and appropriateness of Stay Strong). A brief a new e-MH resource Method: semistructured interviews about barriers, enablers, acceptability and feasibility of use intervention focusing on worries and strengths, and enabling personal and behavioural goalsetting

ignificant

improvements across all measures of skill

and knowledge except for confidence in using computers

(n)

Positive feedback on all aspects of the app. Thematic analysis revealed support for the acceptability feasibility, and

appropriateness of the resource amongst service providers
Negative emotions relating to app compounded by: (1)

historical distrust; (2) the potential for emotional harm (disproportionate to the actual risk) from learning of above average exposure; (3) concerns that the data may misused to stigmatise Anishinaabe culture, and (4) an attitude of communal privacy.

Limited awareness of e-mental health tools prior to training. The ncrease in confidence and knowledge posttraining is promising but it is not known whether this will translate into use.

Simple language and visual appeal were identified as strengths. Participants indicated that the app would be particularly useful for

client engagement, and that it enabled a client-centred approach. Barriers to use include access to

Good completion rates attributed to graphic interface specifically designed for young power and internet.

Help reducing SUDI in the Maori population, the online tool extended education opportunities beyond the traditional face-toface delivery mode and is cost-effective

Testing of the pilot software demonstrates the value of designing culturally adapted risk communication with vulnerable

populations. The app may help to regain community interest and faith in natural resources. The findings support the

assumption that the community seeks to promote the stewardship of natural resources.

E-mental health tools have potential to improve access to culturally appropriate mental health care for Indigenous Peoples with minimal training

but more research required into uptake and use.

e-MH interventions are likely to make an important contribution to overcoming the burden of poor service access for remote Indigenous clients including new delivery ways for health in remote regions

SPARX comprises 7 30- Reductions in min self-administered depression from the efficacy of the SPARX programme for modules 1-2 comMaori; $38 \%$ Pacifica; FZ $56 \%$ male completed symptoms of baseline to week 5 compared to control, pleted / week. CBT-
Delivery online and in

school helped

overcome

embarrassment- a 
Table 5 Summary of research findings from included publications (Continued)

\begin{tabular}{|c|c|c|c|c|c|c|}
\hline $\begin{array}{l}\text { First author (year) } \\
\text { Country } \\
\text { Funding }\end{array}$ & $\begin{array}{l}\text { Study population and } \\
\text { context }\end{array}$ & $\begin{array}{l}\text { Aim/method and } \\
\text { health condition }\end{array}$ & $\begin{array}{l}\text { Intervention and } \\
\text { delivery type }\end{array}$ & $\begin{array}{l}\text { Measured impacts/ } \\
\text { outcomes (results) }\end{array}$ & $\begin{array}{l}\text { Explanations provided } \\
\text { for uptake and effects }\end{array}$ & $\begin{array}{l}\text { Authors' conclusions/ } \\
\text { recommendations }\end{array}$ \\
\hline $\begin{array}{l}\text { Ministry of Health; } \\
\text { NZ Tertiary } \\
\text { Education } \\
\text { Commission }\end{array}$ & $\begin{array}{l}\text { SPARX during school } \\
\text { class time. }\end{array}$ & $\begin{array}{l}\text { depression } \\
\text { Method: Randomised } \\
\text { wait-list control trial. } \\
\text { Immediate vs delayed } \\
\text { treatment (5 weeks). } \\
\text { 10-week follow-up }\end{array}$ & $\begin{array}{l}\text { based content includ- } \\
\text { ing relaxation, problem } \\
\text { solving, activity sched- } \\
\text { uling, challenging } \\
\text { negative thinking and } \\
\text { social skills. }\end{array}$ & $\begin{array}{l}\text { changes sustained 10- } \\
\text { week follow-up. No } \\
\text { significant changes in } \\
\text { anxiety, locus on con- } \\
\text { trol or quality of life. }\end{array}$ & $\begin{array}{l}\text { people and delivery } \\
\text { during class time. } \\
\text { Good uptake occurred } \\
\text { where the programme } \\
\text { was opt-out (i.e. deliv- } \\
\text { ered as part of school } \\
\text { curriculum) rather than } \\
\text { volunteer. }\end{array}$ & $\begin{array}{l}\text { known barrier to help- } \\
\text { seeking. SPARX has } \\
\text { promise as an inter- } \\
\text { vention for young } \\
\text { people who may be } \\
\text { reluctant to engage in } \\
\text { traditional health } \\
\text { services. }\end{array}$ \\
\hline $\begin{array}{l}\text { Fletcher (2017) } \\
\text { [44] } \\
\text { Australia } \\
\text { Funding: Young } \\
\text { and well } \\
\text { Cooperative } \\
\text { Research Centre; } \\
\text { University of } \\
\text { Newcastle }\end{array}$ & $\begin{array}{l}N=20 \text { Aboriginal } \\
\text { fathers aged } 18-25 \text { re- } \\
\text { cruited through } \\
\text { ACCHS and commu- } \\
\text { nity networks in urban, } \\
\text { regional and rural } \\
\text { locations. }\end{array}$ & $\begin{array}{l}\text { Aim: To test the } \\
\text { acceptability and } \\
\text { feasibility a website } \\
\text { with tailored support } \\
\text { to young fathers and } \\
\text { to adapt and test a } \\
\text { mobile phone-based } \\
\text { text message and } \\
\text { mood-tracker program. } \\
\text { Methods: Participatory } \\
\text { qualitative methods } \\
\text { including: "yarn-up" } \\
\text { discussions, filming } \\
\text { fathers' stories, and } \\
\text { SMS messaging. } \\
\text { Participants and }\end{array}$ & $\begin{array}{l}\text { Stayin on Track is a } \\
\text { website with } \\
\text { information, films and } \\
\text { SMS messaging for } \\
\text { young fathers. SMS } \\
\text { was used to monitor } \\
\text { mood and send } \\
\text { encouraging } \\
\text { messages. Participants } \\
\text { were supported by } \\
\text { senior mentors. The } \\
\text { website was promoted } \\
\text { via community } \\
\text { networks and ACCHS } \\
\text { staff. }\end{array}$ & $\begin{array}{l}\text { Links sent by SMS on } \\
\text { parent routines and } \\
\text { "baby talk". } \\
\text { Information on crying, } \\
\text { post-natal depression } \\
\text { and bonding for dads } \\
\text { were not highly } \\
\text { accessed. Most partici- } \\
\text { pants reported positive } \\
\text { mood ( } 91.5 \%) \text {. Com- } \\
\text { munity feedback was } \\
\text { positive. }\end{array}$ & $\begin{array}{l}\text { Key to the success of } \\
\text { the programme was } \\
\text { the close research } \\
\text { partnership with the } \\
\text { communities involved, } \\
\text { and the involvement } \\
\text { of the fathers in } \\
\text { developing the } \\
\text { website content, and } \\
\text { the involvement of } \\
\text { mentors. Online } \\
\text { delivery can help to } \\
\text { overcome barriers to } \\
\text { access to culturally } \\
\text { appropriate resources. }\end{array}$ & $\begin{array}{l}\text { Providing tailored } \\
\text { online resources to } \\
\text { Aboriginal fathers is } \\
\text { feasible and } \\
\text { acceptable. Through } \\
\text { their involvement in } \\
\text { the project, the young } \\
\text { fathers saw themselves } \\
\text { as mentors who could } \\
\text { support other young } \\
\text { men, thus enhancing } \\
\text { project sustainability. } \\
\text { Authors recommend } \\
\text { refining the mentoring } \\
\text { model and conducting } \\
\text { further evaluation. }\end{array}$ \\
\hline
\end{tabular}

\begin{tabular}{|c|c|c|c|}
\hline $\begin{array}{l}\text { Gorman (2013) } \\
\text { [18] } \\
\text { USA } \\
\text { Funding: source } \\
\text { not provided }\end{array}$ & $\begin{array}{l}N=21: 15 \mathrm{Al} / \mathrm{AN} \\
\text { women of child- } \\
\text { bearing age represent- } \\
\text { ing } 9 \text { tribes, and } 6 \text { key } \\
\text { informants in } \\
\text { California. }\end{array}$ & $\begin{array}{l}\text { Aim: To modify and } \\
\text { evaluate a mainstream } \\
\text { web-based behav- } \\
\text { ioural intervention } \\
\text { (SBIRT) on prenatal al- } \\
\text { cohol use for Al/AN } \\
\text { women. } \\
\text { Method: semi- } \\
\text { structured focus } \\
\text { groups and interviews. } \\
\text { Data were transcribed; } \\
\text { cross-case inductive } \\
\text { analysis was used to } \\
\text { identify themes. }\end{array}$ & $\begin{array}{l}\text { Self-administered Web- } \\
\text { based programme for } \\
\text { screening and preven- } \\
\text { tion of prenatal alco- } \\
\text { hol use, with or } \\
\text { without personalised } \\
\text { feedback. }\end{array}$ \\
\hline $\begin{array}{l}\text { ernigan (2011) } \\
\text { SA [19] } \\
\text { Inding: source } \\
\text { ot provided }\end{array}$ & $\begin{array}{l}N=54: 27 \text { Native } \\
\text { American (Al/AN) } \\
\text { representing } 18 \text { tribes } \\
\text { in urban and } \\
\text { reservation settings, } \\
\text { and } 27 \text { non-Native) } \\
\text { participants. All had } \\
\text { diabetes, } 86.5 \% \text { female. } \\
\text { Participants recruited } \\
\text { online. }\end{array}$ & $\begin{array}{l}\text { Aim: to examine the } \\
\text { feasibility and cultural } \\
\text { appropriateness of the } \\
\text { Stanford Internet } \\
\text { Diabetes Self- } \\
\text { Management Work- } \\
\text { shop (IDSMW) with Al/ } \\
\text { AN population. } \\
\text { Method: Mixed } \\
\text { methods process } \\
\text { evaluation. }\end{array}$ & $\begin{array}{l}\text { A 6-week peer-led } \\
\text { internet-based work- } \\
\text { shop covering nutri- } \\
\text { tion, complications, } \\
\text { medications and man- } \\
\text { aging emotions. Partic- } \\
\text { ipants log in three } \\
\text { times/week for } 2 \text { h in- } \\
\text { cluding reading online } \\
\text { content. }\end{array}$ \\
\hline $\begin{array}{l}\text { Kypri (2013) } \\
\text { NZ [28] } \\
\text { Funding: NZ } \\
\text { Alcohol Advisory } \\
\text { Council }\end{array}$ & $\begin{array}{l}N=2355 \text { Maori } \\
\text { students aged } 17-24 \text { at } \\
\text { seven of NZ's } 8 \text { univer- } \\
\text { sities were screened } \\
\text { for harmful alcohol } \\
\text { use (AUDIT-C). Those } \\
\text { screening positive ( } n= \\
\text { 1789) recruited to the } \\
\text { research trial. } N=850 \\
\text { control, } N=939 \\
\text { intervention. }\end{array}$ & $\begin{array}{l}\text { Aim: to test the } \\
\text { effectiveness of a web- } \\
\text { based alcohol screen- } \\
\text { ing and brief interven- } \\
\text { tion (e-SBINZ) for } \\
\text { hazardous drinking } \\
\text { Method: Parallel, } \\
\text { double-blind, multi- } \\
\text { site, randomised con- } \\
\text { trolled trial. Follow-up } \\
\text { questionnaire } 5 \\
\text { months post- } \\
\text { randomisation. }\end{array}$ & $\begin{array}{l}\text { Web-based alcohol } \\
\text { assessment and } \\
\text { personalised feedback } \\
\text { on health risks, other } \\
\text { risks, expenditure and } \\
\text { comparative data, as } \\
\text { well as tips to reduce } \\
\text { harm. The intervention } \\
\text { took }<10 \text { min post } \\
\text { screening. }\end{array}$ \\
\hline
\end{tabular}

\begin{tabular}{|c|c|c|}
\hline $\begin{array}{l}\text { Levine (2009) [20] } \\
\text { USA: } \\
\text { Funding: US Army. } \\
\text { COl: } 2 \text { authors } \\
\text { own stock }(<5 \%) \\
\text { in the company }\end{array}$ & $\begin{array}{l}N=109 \text { AN ( }>18 \\
\text { years) with type } 1 \& 2 \\
\text { diabetes mellitus } \\
\text { recruited via Indian } \\
\text { Health Centers in } \\
\text { Alabama, Idaho, and }\end{array}$ & $\begin{array}{l}\text { Aim: To test whether } \\
\text { interaction with a } \\
\text { web-based diabetes } \\
\text { management app: } \\
\left(\text { MyCareTeam }{ }^{\oplus} \text { ) in- }\right.\end{array}$ \\
\hline
\end{tabular}

The app that provided feedback on blood glucose levels, culturally adapted information, and facilitated timely
5 themes: Make the programme relatable; stress confidentiality: incorporate family/ community focus; tailor content to community; and include information children.
Effectiveness not known. Participatory development processes were essential for building relationships and trust in context where there is low trust of research.
This programme has the potential to provide a culturally appropriate, costeffective approach to assess and prevent prenatal alcohol use.
$23 \mathrm{Al} / \mathrm{AN}$ participants 4 sporadically. Feedback indicated workshop was

culturally acceptable because of the participation of Al/AN people, and that all Al/ AN discussion groups were preferred.

Relative to controls, participants receiving intervention drank less often, less per drinking occasion, less overall and had fewer academic problems. These differences were statistically significant. participated regularly,
The intervention is adaptable due to a peer-led mechanism of delivery. It was considered culturally appropriate with limited adaptation. Participatory approaches to recruitment facilitated implementation.

It is possible to reach large numbers of Maori people with hazardous drinking via the internet. E-SBINZ is extremely low cost. Personalised feedback avoided framing Maori student drinking in terms of deficit.
It is feasible to implement an

Internet-delivered disease self-management workshop within a diverse Al/AN population. Several participants volunteered to be peers in future online workshops.

e-SBINZ reduced hazardous and harmful drinking amongst nonhelp seeking Maori students and has the potential to lead to ongoing public health benefit in the long term, especially with annual implementation in all new Zealand universities. Further generalisability not clear.

Use of the app varied, One of the key with $46 / 109$ using it 2/ month. The more participants used the app, the more they tested their BG and mechanisms by which encouraged HCPthe app worked was patient interaction and increasing the sense of patient-centred comcloseness between the munication, which in patient and HCP, 
Table 5 Summary of research findings from included publications (Continued)

\begin{tabular}{|c|c|c|c|c|c|c|}
\hline $\begin{array}{l}\text { First author (year) } \\
\text { Country } \\
\text { Funding }\end{array}$ & $\begin{array}{l}\text { Study population and } \\
\text { context }\end{array}$ & $\begin{array}{l}\text { Aim/method and } \\
\text { health condition }\end{array}$ & $\begin{array}{l}\text { Intervention and } \\
\text { delivery type }\end{array}$ & $\begin{array}{l}\text { Measured impacts/ } \\
\text { outcomes (results) }\end{array}$ & $\begin{array}{l}\text { Explanations provided } \\
\text { for uptake and effects }\end{array}$ & $\begin{array}{l}\text { Authors' conclusions/ } \\
\text { recommendations }\end{array}$ \\
\hline $\begin{array}{l}\text { that has licensed } \\
\text { MyCareTeam } \\
\text { technology. }\end{array}$ & $\begin{array}{l}\text { Arizona. Gender/age } \\
\text { not reported. }\end{array}$ & $\begin{array}{l}\text { blood glucose (BG) } \\
\text { levels and health care } \\
\text { provider (HCP) } \\
\text { interaction. } \\
\text { Method: non- } \\
\text { randomised prospect- } \\
\text { ive feasibility study. }\end{array}$ & $\begin{array}{l}\text { interaction between } \\
\text { patients and HCPs } \\
\text { through text } \\
\text { messaging. }\end{array}$ & $\begin{array}{l}\text { interacted with their } \\
\text { HCP. The messages } \\
\text { from HCPs seemed to } \\
\text { help motivate use of } \\
\text { the app. }\end{array}$ & $\begin{array}{l}\text { increasing trust and } \\
\text { accountability. The } \\
\text { authors suggest that } \\
\text { apps without this } \\
\text { personal element may } \\
\text { not be as effective. }\end{array}$ & $\begin{array}{l}\text { monitoring. Authors } \\
\text { suggest further re- } \\
\text { search on the relation- } \\
\text { ship between } \\
\text { messaging and clinica } \\
\text { health benefits. }\end{array}$ \\
\hline
\end{tabular}

$\begin{array}{ll}\text { Montag (2015) } & N=263 \text { Al/AN women } \\ \text { [21] } & \text { of child-bearing age in } \\ \text { USA } & \text { Southern California, re- } \\ \text { Funding: National } & \text { cruited via health } \\ \text { Institute of } & \text { clinics. } N=121 \text { inter- } \\ \text { General Medical } & \text { vention } N=142 \text { con- } \\ \text { Sciences } & \text { trol (TAU) }\end{array}$

feasibility study. effectiveness of SBIRT at reducing risky drinking and risk of alcohol-exposed pregnancies (AEP). Method: Randomised trial with follow-up questionnaires at 1,3 and 6 months.

Phillips (2014) [40] $\quad N=53(30$

Australia

Funding:

Australian

Government

Department of

health and Ageing

Hearing Loss

Prevention

Program.
$N=53(30$
intervention, 23 control) caregivers of Aboriginal children living in remote community

households in NT, with access to a mobile phone in the household. (TMP): (i) increased clinic attendance, (ii) improved ear health and (iii) provided a culturally appropriate method of health

\section{Povey (2016) [41] $\quad N=9$ (3 male; 18-60 \\ Australia \\ Funding: Northern \\ Territory (NT) \\ Department of \\ Health years old) Aboriginal and Torres Strait Islander community members without serious mental illness in Darwin, NT.}

SBIRT was an adapted from eCHECKUP TO $\mathrm{GO}$, a brief (20 $\mathrm{min}$ ) intervention

comprising: webbased survey with personalised feedback including analysis of risk, and helpful advice that could be printed out confidentially.

Aim: To test whether One ear health WBTI for families of Multimedia Media children with tympanic Service (MMS) in the membrane perforation local Indigenous

promotion.

Method: multi-centre, parallel group, RCT.

Aim: To explore acceptability of two culturally responsive emental health apps. Method: 3 3-h focus groups. Transcripts were member-checked and analysed thematically.

im: To describe the adaptation of a drug prevention intervention into a low-cost computerbased drug prevention intervention: Honouring Ancient Wisdom and Knowledge

(HAWK2)

Method: Descriptive

review of

development process

Ram (2014) [29]

NZ

Funding: Asthma

Foundation of NZ
$N=761$ consecutive patients and 18 nurses in primary care. $N=44$ were Maori patients, $=18$ Pacifica. Age ranged from 5 to 64 in of Auckland.
Aim: To evaluate the effectiveness of the online intervention at reducing exacerbations, hospital admissions and emergency

presentations, use of corticosteroids and bronchodilator reliance. Method: Retrospective cohort study. Patient data were compared pre-post intervention.

No difference between Baseline factors intervention and control groups. Risky drinking decreased in both groups: drinks week, $(p<0.001)$ frequency binge episodes $/ 2$ weeks, ( $p=$ $0.017)$ and risk of AEP $(p<0.001)$ at 6 months post intervention.

No significant difference between groups in clinic visits per child, healed language sent every 4 perforation, middle ear

days, $\pm 24 \mathrm{~h}$ window discharge or over 6 weeks. Videos were short, animations of Indigenous role models, accompanied by personalised text messages in English with a prompt to visit the clinic.

The AlMhi Stay Strong iPad app is a clinicianassisted therapeutic goal setting tool. iBobbly is a self-help suicide prevention app for mobile device based on acceptance commitment therapy.

HAWK2 comprised 7 lessons, 25-30 min each, which could be implemented flexibly. Total exposure $3.5 \mathrm{~h}$.

luation at the end of each lesson perforation size.

Majority were happy to receive the messages. Ten families in the intervention group reported not receiving the messages.

Findings indicated that acceptability was influenced by characteristics of the person (e.g. menta health), environment (e.g. stigma) and apps (e.g. ease of use

n the final review with, HAWK2 received high mean ratings on likeability (4.8/5), ease of use (4.5/5),

comprehension (4.6/5) and future use (5.0/5). Practitioners also gave positive feedback. associated with

decreased alcohol

consumption at

follow-up included the thinking other women group drink more,

more binge episodes in the past 2 weeks, needing treatment for depression.

Culturally appropriate MMS that could be shared amongst families, the video messages may have been unclear or confusing, and simple text messages may be more effective. Uptake was impacted by events in the community unrelated to the trial.

Uptake and use were reportedly influenced by motivation to change; technological competence; literacy and language; internet or phone access; free download; ease of navigation; cultural relevance, voices, animations.

Strengths were: Recognising the influence of specific cultural and contextual variables; building on an existing evidencebased program; and Integrating community bility are needed. perspectives. that assessment alone, without intervention, may be enough to decrease risky drinking and vulnerability to AEP. Contraceptive could be added to future interventions to reduce vulnerability to AEP.

Mobile phone-based MMS and text messaging intervention was acceptable, but it had no short-term impact ear health. A study over a longer time period may be more informative 4

E-mental health tools can improve the wellbeing of Indigenous people. There was strong support for the concept of e-mental health apps and optimism for their potential. Specific adaptations may aid uptake.

Computer-based interventions are a cost-effective way of engaging youth in prevention programming. Future studies of

Null finding suggests on clinic attendance or

GASP is an online decision support tool for primary care, 
Table 5 Summary of research findings from included publications (Continued)

\begin{tabular}{|c|c|c|c|c|c|c|}
\hline $\begin{array}{l}\text { First author (year) } \\
\text { Country } \\
\text { Funding }\end{array}$ & $\begin{array}{l}\text { Study population and } \\
\text { context }\end{array}$ & $\begin{array}{l}\text { Aim/method and } \\
\text { health condition }\end{array}$ & $\begin{array}{l}\text { Intervention and } \\
\text { delivery type }\end{array}$ & $\begin{array}{l}\text { Measured impacts/ } \\
\text { outcomes (results) }\end{array}$ & $\begin{array}{l}\text { Explanations provided } \\
\text { for uptake and effects }\end{array}$ & $\begin{array}{l}\text { Authors' conclusions/ } \\
\text { recommendations }\end{array}$ \\
\hline $\begin{array}{l}\text { Riddell (2007) [30] } \\
\text { NZ } \\
\text { Funding: Health } \\
\text { Research Council } \\
\text { of NZ; National } \\
\text { Heart Foundation }\end{array}$ & $\begin{array}{l}N=19,164 \text { : Maori = } \\
1450 \text { (7\%). Mean age: } \\
53.2,46 \% \text { female. } \\
\text { Participants attended } \\
\text { "ProCare" primary } \\
\text { health care providers } \\
\text { in Auckland. }\end{array}$ & $\begin{array}{l}\text { Aim: To describe the } \\
\text { cardiovascular disease } \\
\text { (CVD) risk factor status } \\
\text { and risk management } \\
\text { of Maori vs non-Maori } \\
\text { using PREDICT-CVD } \\
\text { Method: Patients } \\
\text { opportunistically } \\
\text { assessed in routine } \\
\text { primary care practice. }\end{array}$ & $\begin{array}{l}\text { PREDICT-CVD is a web- } \\
\text { based clinical decision } \\
\text { support programme } \\
\text { for CVD risk assess- } \\
\text { ment and manage- } \\
\text { ment. It has been } \\
\text { shown to increase } \\
\text { CVD risk assessment } \\
\text { rates in primary care. }\end{array}$ & $\begin{array}{l}\text { Maori were assessed } 3 \\
\text { years younger than } \\
\text { non-Maori. Maori with } \\
\text { CVD received more } \\
\text { anti-coagulants, BP- } \\
\text { lowering and lipid- } \\
\text { lowering medications. } \\
\text { Maori with Ischemic } \\
\text { heart disease were half } \\
\text { as likely to have a } \\
\text { revascularisation } \\
\text { procedure. }\end{array}$ & $\begin{array}{l}\text { An electronic decision } \\
\text { support programme } \\
\text { generated CVD risk } \\
\text { burden and risk } \\
\text { management data for } \\
\text { Maori and non-Maori } \\
\text { populations in routine } \\
\text { clinical practice in real- } \\
\text { time. }\end{array}$ & $\begin{array}{l}\text { When Maori specific } \\
\text { equations replace } \\
\text { those based on a } \\
\text { white, middle-class } \\
\text { American population, } \\
\text { the PREDICT-CVD will } \\
\text { provide a world-class } \\
\text { data system that can } \\
\text { identify gaps in care } \\
\text { for Maori patients and } \\
\text { enable action on } \\
\text { them. }\end{array}$ \\
\hline $\begin{array}{l}\text { Robertson (2007) } \\
{[23]} \\
\text { USA } \\
\text { Funding: South } \\
\text { Dakota State } \\
\text { University } \\
\text { Foundation }\end{array}$ & $\begin{array}{l}N=52 \text { Lakota Sioux } \\
\text { AN with type } 2 \\
\text { diabetes individuals } \\
\text { (33 intervention group, } \\
19 \text { controls), living on } \\
\text { Northern Plains Indian } \\
\text { Reservation, Sioux } \\
\text { Falls, South Dakota. }\end{array}$ & $\begin{array}{l}\text { Aim: To develop and } \\
\text { test a culturally } \\
\text { appropriate web- } \\
\text { based interactive } \\
\text { programme (Keya } \\
\text { Tracker) for manage- } \\
\text { ment of type } 2 \\
\text { diabetes. } \\
\text { Method: Randomised } \\
\text { control trial. Pre-post } \\
\text { data collected on } \\
\text { HbA1c, exercise, diet, }\end{array}$ & $\begin{array}{l}\text { Kaya Tracker was an } \\
\text { interactive website } \\
\text { developed with input } \\
\text { from tribal Elders. } \\
\text { Content covered } \\
\text { nutrition, physical } \\
\text { activity, social and } \\
\text { cultural activities. } \\
\text { Participants logged-in } \\
3 \text { times per week for } \\
24 \text { weeks. }\end{array}$ & $\begin{array}{l}\text { HbA1c control } \\
\text { improved in the } \\
\text { intervention group } \\
\text { relative to controls ( } \mathrm{p} \\
=.025 \text { ), suggesting } \\
\text { improved disease } \\
\text { control and } \\
\text { programme } \\
\text { effectiveness. Four } \\
\text { participants did not } \\
\text { complete the } \\
\text { intervention. }\end{array}$ & $\begin{array}{l}\text { Effectiveness may be } \\
\text { due to the flexibility of } \\
\text { the online delivery. } \\
\text { Also, the website was } \\
\text { designed for its } \\
\text { audience, therefore } \\
\text { accounting for Lakota } \\
\text { Sioux understandings } \\
\text { of health. }\end{array}$ & $\begin{array}{l}\text { Use of a culturally } \\
\text { appropriate Web- } \\
\text { based interactive } \\
\text { programme may be a } \\
\text { viable tool to assess } \\
\text { with diabetes-related } \\
\text { lifestyle change. A lar- } \\
\text { ger study is warranted. }\end{array}$ \\
\hline
\end{tabular}

\begin{tabular}{|c|c|c|}
\hline $\begin{array}{l}\text { Shepherd (2015) } \\
\text { [31] } \\
\text { NZ } \\
\text { Funding: NZ } \\
\text { Ministry of Health; } \\
\text { Rotary Club of } \\
\text { Downtown } \\
\text { Auckland; } \\
\text { University of } \\
\text { Auckland. COl: } 2 \\
\text { authors have } \\
\text { financial interest in } \\
\text { SPARX. }\end{array}$ & $\begin{array}{l}\text { N = } 26 \text { Māori people, } \\
\text { taitamariki } \\
\text { (adolescents); } \\
\text { taitamariki mothers } \\
\text { (aged 16-18); and } \\
\text { whanau (family) in } \\
\text { Auckland. }\end{array}$ & $\begin{array}{l}\text { Aim: To describe } \\
\text { experiences of a } \\
\text { prototype } \\
\text { computerised therapy } \\
\text { programme for } \\
\text { treating mild to } \\
\text { moderate depression. } \\
\text { Method: Mixed } \\
\text { method Kaupapa } \\
\text { Maori research. } 7 \text { focus } \\
\text { groups followed by a } \\
\text { survey. General } \\
\text { Inductive/thematic } \\
\text { analysis was used to } \\
\text { generate themes. }\end{array}$ \\
\hline $\begin{array}{l}\text { Shepherd (2018) } \\
\text { [32] } \\
\text { NZ } \\
\text { Funding: NZ } \\
\text { Ministry of Health; } \\
\text { Rotary Club of } \\
\text { Downtown } \\
\text { Auckland; } \\
\text { University of } \\
\text { Auckland; Te Rau } \\
\text { Matatini }\end{array}$ & $\begin{array}{l}N=6 \text { Māori taitamariki } \\
\text { (adolescents) aged 14- } \\
16 \text { (mean 14.6), in two } \\
\text { schools in the wider } \\
\text { Auckland area. Partici- } \\
\text { pants had mild- } \\
\text { moderate depression } \\
\text { and low risk for self- } \\
\text { harm. }\end{array}$ & $\begin{array}{l}\text { Aim: To explore } \\
\text { adolescents' opinions } \\
\text { about a programme } \\
\text { for treating mild/ } \\
\text { moderate depression } \\
\text { in young people } \\
\text { Method: Exploratory } \\
\text { qualitative study using } \\
\text { semi-structured inter- } \\
\text { views. Thematic } \\
\text { analysis. }\end{array}$ \\
\hline
\end{tabular}

Starks (2015) [24] Multiple groups of Aim: To report on the USA stakeholders consulted multi-year stakeholder Funding: Patient- within South Central engagement process Centred Outcomes Alaska Native for the development

Research Institute Foundation had input of the patient-centred into tool development. "Depression Manage$N=20$ patients and 7 ment - Decision Supservice providers port Tool (DM-DST)". participated in piloting Method: Qualitative the tool.
Method: Qualitative
analysis of multiple data sources including interviews with patients and providers, meeting notes, consultations and pilot testing.
Smart, Positive, Active, Realistic, X-factor thoughts (SPARX) provides free, computerised (CCBT); online computer programme using avatars. Players are led through 7 fantasy "realms" each lasting 30-40 min. 1-2 levels completed over 3-7 weeks.

The SPARX programme is an online, gamified cCBT programme using avatars for treating mild - moderate depression.

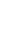

Electronic, patientcentred, depression management decision support tool (DM-DST) with two components: an interactive tool to facilitate discussions between patients and providers and a website with detailed information for patients.

depression and
solutions. There was a
focus on reducing
stigma.

Good face validity; Maori; Whanau are important for young people's wellbeing. Ideas for improvement related to use of clinical and Maori language, reducing text, and using audio. cultural relevance for
Positive evaluation and Participants supported acceptance were aided the contemporary by cultural relevance Maori design of the of both process and program. SPARX was content. Culturally the first programme of adapted mental health its kind and may be interventions are used as a model for thought to be much other CCBT more effective. interventions.
Themes indicated that: Māori designs (1) the programme was helpful because it taught CBT skills; (2) It was engaging due to Maori designs; (3) The characters provided helpful advice; (4) It was both enjoyable and challenging; 5) Writing thoughts and feelings was helpful.

\section{Stakeholder} engagement resulted in substantial modification of the original tool, including breaking it into two parts, incorporating AN imagery and cultural concepts including

faith, family and cultural expressions of solutions. There was stigma. appeared beneficial, as this seemed to enhance cultural identity. SPARX was like a computer game that could help with depression. A breathing relaxation exercise was valued

Multi-stakeholder engaged research allowed the researchers to

understand the diverse values and needs of end-users. The tool was considered interesting, useful, and thought-provoking with the potential to foster conversations with primary care providers.
Māori designs were The ability to customise the characters with Māori enhanced cultural identity. A much larger study should be conducted to explore the efficacy of SPARX.

The process employed as relevance to other primary care systems seeking to improve

and individualise treatments. The tool enhances patientcentred decision making. Future research will test its effectiveness is an RCT. 
Table 5 Summary of research findings from included publications (Continued)

\begin{tabular}{|c|c|c|c|c|c|c|}
\hline $\begin{array}{l}\text { First author (year) } \\
\text { Country } \\
\text { Funding }\end{array}$ & $\begin{array}{l}\text { Study population and } \\
\text { context }\end{array}$ & $\begin{array}{l}\text { Aim/method and } \\
\text { health condition }\end{array}$ & $\begin{array}{l}\text { Intervention and } \\
\text { delivery type }\end{array}$ & $\begin{array}{l}\text { Measured impacts/ } \\
\text { outcomes (results) }\end{array}$ & $\begin{array}{l}\text { Explanations provided } \\
\text { for uptake and effects }\end{array}$ & $\begin{array}{l}\text { Authors' conclusions/ } \\
\text { recommendations }\end{array}$ \\
\hline $\begin{array}{l}\text { Taualii (2010) [25] } \\
\text { USA } \\
\text { Funding: Spirit of } \\
\text { Eagles Special } \\
\text { Populations } \\
\text { Network (NIH) }\end{array}$ & $\begin{array}{l}N=25 \text { urban } \\
\text { American Al/AN } \\
\text { young people, aged } \\
\text { from } 12-18 \text { in Seattle. }\end{array}$ & $\begin{array}{l}\text { Aim: To adapt, modify } \\
\text { and test for useability } \\
\text { an existing smoking } \\
\text { prevention and } \\
\text { cessation resource. } \\
\text { Methods: Focus } \\
\text { groups were } \\
\text { conducted in } 2 \\
\text { phases, first to adapt } \\
\text { and then to test the } \\
\text { usability of the } \\
\text { SmokingZine website. }\end{array}$ & $\begin{array}{l}\text { SmokingZine an e- } \\
\text { health website target- } \\
\text { ing behaviour change } \\
\text { relating to youth } \\
\text { smoking prevention } \\
\text { and cessation. }\end{array}$ & $\begin{array}{l}\text { Participants were } \\
\text { receptive to the use of } \\
\text { the intervention tool } \\
\text { and offered ideas for } \\
\text { changes to make it } \\
\text { more culturally } \\
\text { relevant. In phase 2, } \\
\text { participants found the } \\
\text { site easy to use and } \\
\text { relevant to smoking } \\
\text { cessation. }\end{array}$ & $\begin{array}{l}\text { There was a lot of } \\
\text { overlap between } \\
\text { mainstream and Al/AN } \\
\text { youth perspectives on } \\
\text { smoking. Including } \\
\text { cultural distinctions in } \\
\text { a new website was } \\
\text { acceptable and valued, } \\
\text { although computer } \\
\text { access not ubiquitous. }\end{array}$ & $\begin{array}{l}\text { These findings provide } \\
\text { justification for a full- } \\
\text { scale trial of the Smo- } \\
\text { kingZine website. Fu- } \\
\text { ture research should } \\
\text { include both urban } \\
\text { and rural Al/AN youth } \\
\text { and consider delivery } \\
\text { through schools. }\end{array}$ \\
\hline $\begin{array}{l}\text { Tighe (2017) [42] } \\
\text { Australia } \\
\text { Funding: } \\
\text { Australian } \\
\text { Government } \\
\text { Department of } \\
\text { Health and Ageing }\end{array}$ & $\begin{array}{l}N=62 \text { young men } \\
(22,36 \%) \text { and women } \\
\text { (aged 18-35 years) in } \\
\text { remote communities } \\
\text { in the Kimberley } \\
\text { region of north- } \\
\text { Western Australia. } 4 \\
\text { were non-Aboriginal, } \\
\text { the remainder were } \\
\text { Aboriginal and/or } \\
\text { Torres Strait Islander. }\end{array}$ & $\begin{array}{l}\text { Aim: To evaluate the } \\
\text { effectiveness of a self- } \\
\text { help mobile app for } \\
\text { suicide prevention. } \\
\text { Method: Randomised } \\
\text { waitlist control trial. } \\
\text { Measures were taken } \\
\text { face-to-face at baseline } \\
\text { and after the interven- } \\
\text { tion for both groups. } \\
\text { The control group had }\end{array}$ & $\begin{array}{l}\text { iBobbly was a mobile } \\
\text { app that targets } \\
\text { suicidal ideation, } \\
\text { depression, } \\
\text { psychological distress } \\
\text { and impulsivity using } \\
\text { Acceptance } \\
\text { Commitment Therapy } \\
\text { approaches. Three } \\
\text { content modules and } \\
\text { three self-assessments, }\end{array}$ & $\begin{array}{l}\text { Data were available for } \\
40 \text { participants. } \\
\text { Significant pre/post } \\
\text { changes on suicide } \\
\text { ideation in the iBobbly } \\
\text { arm ( } p=0.0195) \text {, but } \\
\text { not when compared } \\
\text { with waitlist arm. } \\
\text { iBobbly group showed } \\
\text { reductions in } \\
\text { depression and }\end{array}$ & $\begin{array}{l}\text { Uptake was aided by } \\
\text { the collaborative } \\
\text { development process. } \\
\text { Acceptance was } \\
\text { indicated by the } \\
\text { promotion of the app } \\
\text { by the target } \\
\text { community. Technical/ } \\
\text { connectivity failure } \\
\text { prevented some from } \\
\text { providing final data. }\end{array}$ & $\begin{array}{l}\text { The app, using } \\
\text { acceptance-based } \\
\text { therapy reduced dis- } \\
\text { tress and depression } \\
\text { but did not show sig- } \\
\text { nificant reductions on } \\
\text { suicide ideation or im- } \\
\text { pulsivity. Study } \\
\text { highlighted the im- } \\
\text { portance of co-design. }\end{array}$ \\
\hline
\end{tabular}

$\begin{array}{ll}\text { Tonkin (2017) [45] } & N=36 \text { smartphone } \\ \text { Australia } & \text { users (aged 18-35 } \\ \text { Funding: NHMRC; } & \text { years) in two remote } \\ \text { National Heart } & \text { Indigenous } \\ \text { Foundation; NT } & \text { communities in NT. } \\ \text { Government } & \text { There were 10 } \\ \text { Department of } & \text { participants per } \\ \text { Health } & \begin{array}{l}\text { community in each } \\ \text { phase of research. }\end{array}\end{array}$

Verbiest (2018)
[33]

NZ

Funding: Healthier Lives He Oranga Hauora National Science Challenge
Partnership between Maori, Pasifika and European academics, Maori health providers and community members in

Wellington and Auckland regions.

$\begin{array}{ll}\text { Whittaker (2006) } & 80 \text { General } \\ {[34]} & \text { Practitioners (GPs) } \\ \text { NZ } & \text { providing care to } \\ \text { Funding: } & \text { Maori and non-Maori } \\ \text { Waitemata District } & \text { people in New Zea- } \\ \text { Health Board; } & \text { land. } N=474(28.2 \%) \\ \text { Future Forum; } & \text { Maori patients pre- } \\ \text { National Heart } & \text { and } n=484(25.7 \%) \\ \text { Foundation } & \text { post- intervention. }\end{array}$

Aim: To develop and test a prototype app to improve nutritional intake relating to

sugar-sweetened beverages (SSB).

Method: Formative

phase included

simulated grocery

selection activity, semistructured interview, and survey. End-user testing phase involved a "think aloud" test and interview on user satisfaction.

Aim: (a) to provide overview of co-design methods and processes; (b) to describe how co-design was used to select behavioural determinants and change techniques.

Method: 6-step participatory co-design process conducted over 11 months. Focus groups, photographs, notes and observations were thematically analysed.

Aim: To determine if an electronic assessment and

management tool for CVD could increase risk assessment but not inequalities.

Method: Retrospective audit of GPs using the tool's electronic medical records (EMRs)

Self-administered Smartphone app including assessment and feedback on SSB intake, behavioural challenges, interactive exercises and games.

distress scores

compared with

waitlist. Waitlist

improved after 6 weeks of app use.

Drivers of food choice/ behaviour included taste, family, health price and convenience. Mixed methods data on usability indicated that participants found the app useful \& were confident using it, with some suggested modifications.

Complex set-up and log-in inhibit use. Dissemination of apps should be contextually embedded with many avenues available. Learnings about the social dynamics of remote communities in this study may have relevance to other disadvantaged communities.

Self-administered mHealth tool (smartphone app) for prevention of noncommunicable disease, incorporating contemporary Maori and Pasifika theoretical frameworks of health and health promotion. physical activity, (b) family, and (c) healthy eating (including fruit and vegetable gardening; Table 1). Māori community partners identified additional ethnicspecific themes relevant for overall Māori health and wellbeing.
Recommendations included: formative research needs to be prioritised in project plans; use mixed methods; patterns of technology use may be different in different locations; include non-written communication; local language; engaging graphics.
Authors suggest future tailored, lifestyle support (mHealth) interventions for Indigenous and other priority groups should be co-designed and look beyond Western approaches to ensure they are evidencebased and culturally relevant.
PREDICT-CVD is a web- Maori participants based decision support were significantly tool to facilitate risk as- different from nonsessment for GPs to use in the management of CVD in primary care.
Maori on all measured parameters. Maori were younger, had more diabetes, lower SES and higher rate of smoking. Rate of risk assessment increased in both groups.
Rates of documented risk assessment were low overall. $7.2 \%$ of audited EMRs had no ethnicity stated and coded as non-Maori, which may have resulted in under- count- needs of those at risk ing of Maori.
The implementation of the tool should not occur without an implementation program, and other changes to increase responsiveness to the of CVD, such as taking risk assessment into community settings. 
availability of infrastructure [15, 23, 39-41], underlying burden of disease [29] and funding to reduce the cost to end-users [31, 41].

\section{Recommendations and conclusions from the sources}

Culturally appropriate, evidence-based WBTI have the potential to improve mental health [27, 32, 42], address substance abuse treatment barriers [16], improve selfefficacy and self-management in healthcare $[23,26]$ and reduce inequalities in access to healthcare services, for Indigenous communities. WBTI are a cost-effective method of delivering information and engaging target populations, such as youth $[22,28]$ and pregnant women [18], to reduce hazardous and harmful alcohol intake. In fact, one source reported that using a WBTI to selfassess risky drinking behaviour may be enough to influence behavioural change, without implementation of an intervention [21].

Thus far, evaluations of smoking cessation WBTI for Indigenous populations have been limited to America $[15,25]$. These evaluations concluded that additional long-term, rigorous research is needed to assess WBTI approaches to keep American Indian and Alaskan Native youth from becoming regular smokers [15] and that future research needs to include both urban and rural Indigenous youth [25], highlighting that to date no online tobacco programmes have been designed specifically for these populations [15].

Sources that evaluated the use of mental health WBTI for Indigenous populations concluded that these interventions are likely to be important in overcoming poor access to services for remote communities [39, 43], or for youth that might be reluctant to engage in traditional health services [27]. Further, developing WBTI in partnership with Indigenous communities ensures culturally appropriate interventions that are accepted and promoted by the communities [24, 31-33, 42, 44], and lead to improved wellbeing of Indigenous people [41]. In addition, improved access to culturally appropriate WBTI tools, and training in how to use these tools, allows mental health workers to better support their Indigenous clients [36, 37, 39].

Cardiovascular disease risk data for Maori people can be successfully generated in real time through the use of an electronic decision support tool [30]. In addition, cardiac rehabilitation care delivered through WBTI platform has the potential to significantly improve outcomes for Indigenous populations [38]. However, other researchers suggest that the use of WBTI for cardiac care should not occur in isolation, instead emphasising that WBTI should be complemented by a comprehensive care program [34].

Implementing culturally appropriate WBTI for the selfmanagement of diabetes has been shown to be feasible
[19]. The use of such platforms has been shown to improve diabetes control in Indigenous populations [23], possibly because these interventions may increase the frequency patients monitor their blood glucose levels [20].

The remainder of sources identified for inclusion in this review also recommended WBTI as positively supporting Indigenous communities. WBTI were shown to have the potential to be a useful tool for dieticians working to optimise the food and nutrient intakes of pregnant women [35] and may reduce sudden unexpected infant deaths by increasing education beyond traditional face-to-face delivery methods [26]. Research demonstrated the importance of designing culturally appropriate WBTI to promote health through understanding and use of natural resources [17], to increase ear health knowledge [40] and to improve asthma education [29].

\section{Discussion}

The purpose of this review was to identify and describe the available international scientific evidence on WBTI used by Indigenous peoples in Australia, New Zealand, Canada and USA for managing and treating health conditions. As mobile devices, including smart phones, become ubiquitous in the general population, web-based and other electronic interventions are increasing in number and scope. This is indicated by an increase in studies on the topic year on year, and of the many protocols that were excluded from this scoping review, but which clearly indicate a growing field with many studies planned or underway. The results indicate that while WBTI are most commonly designed to manage mental health and substance use issues, they are increasingly being incorporated in the range of treatment and support options for a variety of health conditions and are being used by those with the health condition or by service providers.

The popularity of WBTI stems in part from their potential reach, which extends to anyone in any geographical location or social context where they have access to the internet and a device capable of running the program. While increases in internet access amongst Indigenous populations in Australia, New Zealand, Canada and USA have been reported, in each of these countries, a "digital divide" across ethnic and geographical lines also exists, with Indigenous households and individuals having less access to the internet overall, and internet access being lowest in those geographical areas with the highest proportion of Indigenous residents [46]. The lack of any studies from Canada meeting the inclusion criteria was surprising, however there is evidence that other forms of ICT, such as telehealth, are in use in Canada, and that First Nations communities are engaging with and developing digital health technologies in line with Indigenous models of health and wellbeing [47]. 
The available data indicates that young people tend to have greater internet access and use [48] so it is perhaps not surprising that adolescents or young people were the focus of a large proportion of studies (8/34). Indigenous populations in Australia, USA, Canada and New Zealand are younger than the general populations in each country [46, 49-51], so interventions designed to improve the wellbeing of young people are particularly relevant. However, there were several studies of WBTI focusing on chronic diseases such as diabetes and cardiovascular disease that are relevant to older people.

Perhaps the most common and clear lesson articulated by study authors was the importance of developing programmes in collaboration with the target communities. In this sense, WBTI are no different to other interventions, with issues of governance and ownership being central not only to the ethical delivery of programmes but also to their acceptability, feasibility and effectiveness. Several authors cited "co-design" or collaborative design as strengths of their projects. Having the target community involved in all aspects of intervention and study design is in line with ethical guidelines for research with Indigenous peoples internationally [52-55].

Meta-analysis of effectiveness was beyond the remit of this scoping review, and while such analysis is likely to be limited by the small sample sizes evident in these studies, future research could usefully examine both the effectiveness and cost-effectiveness of WBTI with Indigenous people. Cost-effectiveness is frequently highlighted as an advantage of WBTI. However, few studies include analysis of cost-effectiveness that incorporates the often-substantial costs of development that may occur over lengthy time periods. This scoping review was limited in the degree to which it could examine barriers to accessing WBTI resulting from cultural and linguistic diversity, low health literacy, limited digital capabilities and infrastructural and resource limitations for individuals and communities in different geographic locations. This review is also based on a definition of health that is less holistic and relational than Indigenous models of health and wellbeing tend to be [1]. Future research could focus more explicitly on a broader range of social health factors, such as language use and reclamation, as these are likely to have health benefit from an Indigenous perspective [56]. Broadening the review to include digital sources, such as app stores and social media, could also provide a more comprehensive account of all indigenous-focused WBTI and tools, although formal evaluations of such interventions, which are the focus of this review, are unlikely to be sourced this way.

As mobile digital devices become cheaper and more widespread, and internet technology improves in speed and geographic coverage, it seems safe to assume that
WBTI will also become more widespread, and of interest to health services and commercial entities who may wish to exploit potential markets. This is true for Indigenous peoples as it is for others, although the smaller population size may limit commercial interest in Indigenousspecific WBTI and explain the propensity of funding from government rather than commercial sources. As the field grows, ensuring that technologies accessed in Indigenous communities are high quality, evidencebased, culturally appropriate, inclusive and accessible will require that we continue to examine and re-examine the evidence as it emerges and that Aboriginal communities continue to lead the development of technologies that best meet their needs.

\section{Supplementary information}

Supplementary information accompanies this paper at https://doi.org/10 1186/s13643-020-01374-x.

Additional file 1. Preferred Reporting Items for Systematic reviews and Meta-Analyses extension for Scoping Reviews (PRISMA-SCR) Checklist.

\section{Acknowledgements}

The authors would like to thank Maureen Bell, Research Librarian at the University of Adelaide, for her assistance with the development of the search strategy, and Frida Svensson for her excellent project management. This research was conducted as part of a National Health and Medical Research Council funded project (\#APP1100696). JW is Sylvia and Charles Viertel Senior Medical Research Fellow.

\section{Authors' contributions}

$\mathrm{RR}, \mathrm{SH}, \mathrm{CT}$ developed and tested search terms. RR conducted the searches and was primary reviewer. IF, SH, CT, OP and JW contributed to secondary review and data extraction. JM and JS assited with data charting and summarising. RR drafted the final manuscript with JS and JM, and all authors read and approved the final manuscript.

\section{Competing interests}

The authors declare that they have no competing interests.

\section{Author details}

${ }^{1}$ Aboriginal Health Equity, South Australian Health and Medical Research Institute, Adelaide, South Australia, Australia. ${ }^{2}$ College of Medicine and Public Health, Flinders University, Bedford Park, South Australia, Australia. ${ }^{3}$ School of Medicine, University of Adelaide, Adelaide, Australia. ${ }^{4}$ Rosemary Bryant AO Research Centre, Clinical and Health Sciences, University of South Australia, Adelaide, South Australia, Australia. ${ }^{5}$ Australian Institute of Health Innovation, Macquarie University, Sydney, New South Wales, Australia. ${ }^{6}$ Institute of Urban Indigenous Health, Windsor, Queensland, Australia.

Received: 18 December 2019 Accepted: 28 April 2020

Published online: 31 May 2020

References

1. Pulver $L$, Haswell MR, Ring I, Waldon J, Clark W, Whetung V, Kinnon D, Graham C, Chino M, La Valley J, et al. Indigenous health - Australia, Canada, Aotearoa New Zealand and the United States - Laying claim to a future that embraces health for us all. In: World Health Organisation. Geneva: World Health Organisation; 2010.

2. WHO Global Observatory for eHealth. mHealth: New horizons for health through mobile technologies. In: Global Observatory for eHealth series. Volume 3. Geneva: World Health Organisation; 2011.

3. Zeng EY, Vilardaga R, Heffner JL, Mull KE, Bricker JB. Predictors of Utilization of a Novel Smoking Cessation Smartphone App. Telemed J E Health. 2015; 21(12):998-1004 
4. Rennie E, Yunkaporta T, Hulcombe-James I. Cyber safety in remote Aboriginal communities: Final Report. Melbourne: Digital Ethnography Research Centre; 2018.

5. Rice ES, Haynes E, Royce P, Thompson SC. Social media and digital technology use among Indigenous young people in Australia: a literature review. Int J Equity Health. 2016;15(84):81.

6. Ellway D, Reilly R, LeCouteur A, Ward J. Exploring how people affected by methamphetamine exchange social support through online interactions on Facebook: content analysis. JMIR Mental Health. 2019;6(10):e14011.

7. Sweet MA. Social media: New links for indigenous health. Med J Aus. 2013; 199(1):18.

8. Australian Government. Safe, seamless and secure: evolving health and care to meet the needs of modern Australia. Australia's National Digital Health Strategy. Canberra: Australian Government Australian Digital Health Agency; 2018.

9. Brusse C, Gardner K, McAullay D, Dowden M. Social media and mobile apps for health promotion in Australian Indigenous populations: scoping review. JMIR. 2014;16(12):e280.

10. Shahid S, Thompson S. Authors' response. Aus NZ J Public Health. 2010; 34(1):91-2.

11. Gibson O, Reilly R, Harfield S, Tufanaru C, Ward J. Web-based therapeutic interventions for assessing, managing and treating health conditions in Indigenous people: a scoping review protocol. JBI Database System Rev Implement Rep. 2017;15(10):2487-94.

12. Khalil H, Peters M, Godfrey CM, Mclnerney P, Soares CB, Parker D. An Evidence-Based Approach to Scoping Reviews. Worldviews Evid-Based Nurs. 2016;13(2):118-23.

13. Peters MD, Godfrey CM, Khalil H, Mclnerney P, Parker D, Soares CB. Guidance for conducting systematic scoping reviews. Int J Evid Based Healthc. 2015;13(3):141-6.

14. Tricco AC, Lillie E, Zarin W, O'Brien KK, Colquhoun H, Levac D, Moher D, Peters MDJ, Horsley T, Weeks L, et al. PRISMA Extension for Scoping Reviews (PRISMA-SCR): Checklist and Explanation. Ann Intern Med. 2018; 169(7):467-73

15. Bowen DJ, Henderson PN, Harvill J, Buchwald D. Short-term effects of a smoking prevention website in American Indian youth. JMIR. 2012;14(3):e81.

16. Campbell AN, Turrigiano E, Moore M, Miele GM, Rieckmann T, Hu MC, Kropp F, Ringor-Carty R, Nunes EV. Acceptability of a web-based community reinforcement approach for substance use disorders with treatment-seeking American Indians/Alaska Natives. Community Ment Health J. 2015;51(4):393-403.

17. Dellinger MJ, Olson J, Clark R, Pingatore N, Ripley MP. Development and pilot testing of a model to translate risk assessment data for Great Lakes Native American communities using mobile technology. Hum Ecol Risk Assess. 2018;24(1):242-55.

18. Gorman JR, Clapp JD, Calac D, Kolander C, Nyquist C, Chambers CD. Creating a culturally appropriate web-based behavioral intervention for American Indian/Alaska Native women in Southern California: the healthy women healthy Native nation study. Am Indian Alsk Native Ment Health Res. 2013;20(1):1-15

19. Jernigan VBB, Lorig K. The Internet Diabetes Self-Management Workshop for American Indians and Alaska Natives. Health Promot Pract. 2011;12(2):261-70.

20. Levine BA, Turner JW, Robinson JD, Angelus P, Hu TM. Communication plays a critical role in web-based monitoring. J Diabetes Sci Technol. 2009;3(3):461-7.

21. Montag AC, Brodine SK, Alcaraz JE, Clapp JD, Allison MA, Calac DJ, Hull AD, Gorman JR, Jones KL, Chambers CD. Preventing alcohol-exposed pregnancy among an American Indian/Alaska Native population: effect of a screening, brief intervention, and referral to treatment intervention. Alcohol Clin Exp Res. 2015:39(1):126-35.

22. Raghupathy S, Forth ALG. The HAWK2 program: A computer-based drug prevention intervention for Native American youth. Am J Drug Alcohol Abuse. 2012;38(5):461-7.

23. Robertson C, Kattelmann K, Ren C. Control of type 2 diabetes mellitus using interactive internet-based support on a Northern Plains Indian reservation: a pilot study. Top Clin Nutr. 2007;22(2):185-93

24. Starks H, Shaw JL, Hiratsuka V, Dillard DA, Robinson R. Engaging stakeholders to develop a depression management decision support tool in a tribal health system. Qual Life Res. 2015;24(5):1097-105.

25. Taualii M, Bush N, Bowen DJ, Forquera R, Taualii M, Bush N, Bowen DJ, Forquera R. Adaptation of a smoking cessation and prevention website for urban American Indian/Alaska Native youth. J Cancer Educ. 2010;25(1):23-31.
26. Cowan S, Pease A, Bennett S. Usage and impact of an online education too for preventing sudden unexpected death in infancy. J Paediatr Child Health. 2013;49(3):228-32.

27. Fleming T, Dixon R, Frampton C, Merry S. A pragmatic randomized controlled trial of computerized CBT (SPARX) for symptoms of depression among adolescents excluded from mainstream education. Behav Cog Psychotherapy. 2012;40(5):529-41.

28. Kypri K, McCambridge J, Vater T, Bowe SJ, Saunders JB, Cunningham JA, Horton NJ. Web-based alcohol intervention for Maori university students: double-blind, multi-site randomized controlled trial. Addiction. 2013;108(2): 331-8.

29. Ram FS, McNaughton W. Giving Asthma Support to Patients (GASP): a novel online asthma education, monitoring, assessment and management tool. J Prim Health Care. 2014;6(3):238-44.

30. Riddell T, Jackson RT, Wells S, Broad J, Bannink L. Assessing Maori/non-Maori differences in cardiovascular disease risk and risk management in routine primary care practice using web-based clinical decision support: (PREDICT CVD-2). N Z Med J. 2007;120(1250):U2445.

31. Shepherd M, Fleming T, Lucassen M, Stasiak K, Lambie I, Merry SN. The design and relevance of a computerized gamified depression therapy program for Indigenous Maori Adolescents. JMIR Serious Games. 2015;3(1):e1.

32. Shepherd M, Merry S, Lambie I, Thompson A. Indigenous adolescents' perception of an eMental Health Program (SPARX): exploratory qualitative assessment. JMIR Serious Games. 2018;6(3):e13.

33. Verbiest MEA, Corrigan C, Dalhousie S, Firestone R, Funaki T, Goodwin D, Grey J, Henry A, Humphrey G, Jull A, et al. Using codesign to develop a culturally tailored, behavior change mHealth intervention for indigenous and other priority communities: A case study in New Zealand. Transl Behav Med. 2018.

34. Whittaker R, Bramley D, Wells S, Stewart A, Selak V, Furness S, Rafter N, Roseman P, Jackson R. Will a web-based cardiovascular disease (CVD) risk assessment programme increase the assessment of CVD risk factors for Maori? N Z Med J. 2006;119(1238):U2077.

35. Ashman AM, Collins CE, Brown $\sqcup$, Rae KM, Rollo ME. A brief tool to assess image-based dietary records and guide nutrition counselling among pregnant women: an evaluation. JMIR Mhealth Uhealth. 2016;4(4):e123.

36. Bennett-Levy J, Singer J, DuBois S, Hyde K. Translating E-Mental health into practice: what are the barriers and enablers to E-Mental health implementation by Aboriginal and Torres Strait Islander Health Professionals? JMIR. 2017;19(1).

37. Bird J, Rotumah D, Bennett-Levy J, Singer J. Diversity in eMental Health Practice: An Exploratory Qualitative Study of Aboriginal and Torres Strait Islander Service Providers. JMIR Ment Health. 2017:4(2):e17.

38. Bradford D, Hansen D, Karunanithi M. Making an APPropriate care program for indigenous cardiac disease: customization of an existing cardiac rehabilitation program. Stud Health Technol Inform. 2015;216:343-7.

39. Dingwall KM, Puszka S, Sweet M, Mills PPJR, Nagel T. Evaluation of a culturally adapted training course in Indigenous e-mental health. Australasian Psychiatry. 2015;23(6):630-5.

40. Phillips JH, Wigger C, Beissbarth J, McCallum GB, Leach A, Morris PS. Can mobile phone multimedia messages and text messages improve clinic attendance for Aboriginal children with chronic otitis media? A randomised controlled trial. J Paediatr Child Health. 2014:50(5):362-7.

41. Povey J, Mills PP, Dingwall KM, Lowell A, Singer J, Rotumah D, Bennett-Levy J, Nagel T. Acceptability of mental health apps for Aboriginal and Torres Strait Islander Australians: a qualitative study. JMIR. 2016;18(3):e65.

42. Tighe J, Shand F, Ridani R, Mackinnon A, De La Mata N, Christensen H. Ibobbly mobile health intervention for suicide prevention in Australian Indigenous youth: a pilot randomised controlled trial. BMJ Open. 2017;7(1).

43. Dingwall KM, Puszka S, Sweet M, Nagel T. "Like drawing into sand": acceptability, feasibility, and appropriateness of a new e-mental health resource for service providers working with Aboriginal and Torres Strait Islander People. Aus Psychol. 2015;50(1):60-9.

44. Fletcher R, Hammond C, Faulkner D, Turner N, Shipley L, Read D, Gwynn J. Stayin' on track: the feasibility of developing internet and mobile phone based resources to support young Aboriginal fathers. Aus J Primary Health. 2017;23(4):329-34.

45. Tonkin E, Jess L, Wycherley TP, Maher C, Smith R, Hart J, Cubillo B, Nut BH, Brimblecombe J. A smartphone app to reduce sugar-sweetened beverage consumption among young adults in Australian remote Indigenous communities: Design, formative evaluation and user-testing. JMIR Mhealth Uhealth. 2017;5(12):e192 
46. Australian Bureau of Statistics. 2071.0 - Census of Population and Housing: Reflecting Australia - Stories from the Census, 2016. Canberra: ABS; 2017.

47. Hensel JM, Ellard K, Koltek M, Wilson G, Sareen J. Digital health solutions for indigenous mental well-being. Curr Psychiatr Rep. 2019;21(8):68.

48. Australian Bureau of Statistics. 8146.0 - Household Use of Information Technology, Australia, 2016-17. Canberra: ABS; 2017.

49. Statistics Canada. Focus on Geography Series, 2016 Census. Ottawa: Statistics Canada Catalogue no. 98-404-X2016001; 2017

50. United States Census Bureau. 2017 American Community Survey. Suitland: United States Census Bureau; 2017.

51. Stats NZ. How is our Maori population changing? Wellington: Stats NZ; 2015.

52. National Health and Medical Research Council. Values and ethics: guidelines for ethical conduct in Aboriginal and Torres Strait Islander Health Research. Canberra: NHMRC; 2003.

53. Hudson M, Milne M, Reynolds P, Russell K, Smith B. Te Ara Tika: guidelines for Maori research ethics: a framework for researchers and ethics committee members. Auckland: Health Research Council of New Zealand; 2010.

54. Government of Canada. Chapter 9: Research Involving the First Nations, Inuit and Métis Peoples of Canada. In: Tri-Council Policy Statement: Ethical conduct for research involving humans. Ottawa: Secretariat on Responsible Conduct of Research; 2018.

55. Kelley A, Belcourt-Dittloff A, Belcourt C, Belcourt G. Research ethics and indigenous communities. Am J Public Health. 2013;103(12):2146-52.

56. Sivak L, Westhead S, Richards E, Atkinson S, Richards J, Dare H, Zuckermann G, Gee G, Wright M, Rosen A, et al. "Language breathes life" - Barngarla community perspectives on the wellbeing impacts of reclaiming a dormant Australian Aboriginal language. Int J Environ Res Public Health. 2019; 16(3918).

\section{Publisher's Note}

Springer Nature remains neutral with regard to jurisdictional claims in published maps and institutional affiliations.

Ready to submit your research? Choose BMC and benefit from:

- fast, convenient online submission

- thorough peer review by experienced researchers in your field

- rapid publication on acceptance

- support for research data, including large and complex data types

- gold Open Access which fosters wider collaboration and increased citations

- maximum visibility for your research: over $100 \mathrm{M}$ website views per year

At $\mathrm{BMC}$, research is always in progress.

Learn more biomedcentral.com/submissions 